Improving Adult Literacy Without Improving The Literacy of Adults? A Cross-National Cohort Analysis

Bilal Barakat

Email: bilal.barakat@oeaw.ac.at

Affiliation: Vienna Institute of Demography (VID)

Mail: Welthandelsplatz 2 / Level 2, 1020 Vienna, Austria

Phone: +43(0) 131336 - 7720

Fax: $\quad+43(0) 131336-907702$ 


\title{
Improving Adult Literacy Without Improving The Literacy of Adults? A Cross-National Cohort Analysis
}

\begin{abstract}
There is a potential disconnect between adult literacy initiatives on the one hand and the indicators typically employed to operationalise their targets and measure their progress on the other. Specifically, the policy discourse is typically framed in terms of illiterate adults becoming literate, while changes in the main indicator, the overall adult literacy rate, may instead be driven by literate youth becoming adults. The aim of this study is to quantify the relative contribution of these two factors (adult literacy acquisition and cohort replacement) in order to understand the extent to which the latter needs to be taken into account in assessing the progress achieved towards the Education for All (EFA) literacy target. Using DHS data on the education and measured (rather than self-reported) literacy status of women aged 20 to 49 for 30 countries to examine changes in literacy along cohort lines (while bounding the possible distortion due to migration and differential mortality), I demonstrate how much of the increase in the overall adult literacy rate is due to literate youth becoming adults, rather than illiterate adults becoming literate. The results show that in most countries, observed gains in overall adult literacy greatly overstate the degree to which adults have gained literacy at adult ages. Some countries do exhibit changes in literacy along cohort lines that cannot be easily attributed to selective migration or mortality and may indicate 'true' gains or losses in individual literacy. The finding that the cohort effect is of large magnitude in practice has significant implications for research on and design of literacy policies: relying on an indicator that conflates two distinct goals, namely of increasing the share of literate adults and of helping illiterate adults become literate, results in misleading policy conclusions. This affects both the retrospective assessment of policy success and failure (and its causes), and the prospective assessment of the challenges in meeting 'one size fits all' literacy goals faced by countries with very different population dynamics. This insight is particularly timely given the opportunity presented by the beginning of the new Sustainable Development agenda to reconsider the monitoring of improvements in adult literacy around the globe.
\end{abstract}

Keywords: adult literacy, MDGs, cohort analysis, DHS 


\section{Acknowledgements}

This study was partly funded by the Austrian Science Fund (FWF): Z171- G11. The analyses presented here rely on the generous provision of microdata for scientific use by ICF International's DHS Program, and by the national statistical agencies of Brazil, India, and Indonesia, through the IPUMS International project at the Minnesota Population Center. 


\section{Introduction}

Literacy programming is premised on the notion that illiterate adults can become literate. This notion is clearly articulated in the vast literature on adult literacy education. Robinson $(2005,436)$ places adult literacy 'in the broader context of adult learning', and notes that 'the very diversity of adult literacy provision requires approaches which differ markedly from those implied in the provision of schooling' (p. 442). 'Adult learners' are recognised as a priority group (Hamilton \& Pitt 2011, 597), as is the understanding that literacy programmes for adults are among the modes of realizing the Education for All (EFA) goals (Dyer 2000, 241). This understanding is likewise made explicit in international policy documents. Examples include both the EFA framework itself (Dakar Framework for Action, Education for All: Meeting Our Collective Commitments 2000), the 'Expanded Commentary' (p. 16), and the regional framework for Africa, for example. There, it is stated explicitly that the goal is to '[r]educe illiteracy rates by at least 50 per cent, by consolidating adult literacy and continuing education as part of lifelong learning' (emphasis added) (p. 31).

Both the goal, and the monitoring of progress towards it, are commonly expressed in terms of the Adult Literacy Rate (ALR). This indicator is straightforward to define as the share among the adult population that is literate. Unfortunately, the utility of the ALR for assessing the success of literacy campaigns is hampered by the fact that this indicator is based on a different adult population at different points in time. As a result, even if not one adult changes his or her literacy status, the adult literacy rate may increase or decline, purely through composition effects. Put succinctly, 'the overall illiteracy rates for the population aged 15 years and over tend to decrease over time as younger cohorts with lower rates are added, while the older ones with higher rates disappear as their members die off' (Cárceles 1990, 5). In other words, adult literacy rates for a given population can improve over time (as the real number of literate adults increases), even in situations where not a single illiterate adult was made literate. For some purposes, notably the demand for literacy programming, it may not actually matter whether illiterate adults were replaced by literate adults rather than changed their status, and the ALR as such is a perfectly serviceable indicator. Findings that a larger stock of literate adults is benefitial for economic development (Bhargava 2008) or child health (Schell et al. 2007) are not conditional on whether this is due to 'new literate adults' versus 'newly literate adults'. Even then, the gains are gained sooner as returns to adult education, and only with a considerable 
time lag as returns to child education. Moreover, the difference clearly matters with respect to measuring social progress as articulated in international development frameworks such as the MDGs and now the Sustainable Development Goals (SDGs), because this involves improving the lives of existing illiterates.

Differential mortality and migration may further change the composition of the adult population in ways that affect the ALR. This would be the case if literates and illiterates are subject to different risks of dying in a given time period, or to different rates of migration. Neither of these are implausible, and indeed such differentials can be observed both in industrialised societies (Bostock and Steptoe 2012) and developing countries (Grosse and Auffrey 1989) and assumed health benefits at least are one of the rationales for investing in adult literacy in the first place.

As a result, the trajectory of adult literacy can and does differ substantially depending on whether we look at a fixed aged group in cross-section (i.e. the ALR) or at fixed cohorts over age (Fig. 1). More on these graphs will be said further below. To preview some of the findings: the cohort perspective tends to display a lack of adult literacy transitions, even when the ALR is increasing continuously. Analysing literacy trends along cohort lines therefore provides an important complementary perspective, particularly if in addition to investigating its consequences we seek to understand changes in adult literacy and their possible causes. Yet such a perspective is applied surprisingly rarely outside of studies of lifelong learning in industrialised countries (Reder and Bynner 2008). Indeed, it has yet to be applied quantitatively with respect to assessing the progress that was made towards the 2015 Dakar goal of 'achieving a 50 per cent improvement in levels of adult literacy by 2015, especially for women, and equitable access to basic and continuing education for all adults', despite the fact that the cohort perspective is far from new with respect to global literacy. In fact, over 25 years ago, Cárceles (1990) observed that the literacy rates of matched cohorts are relatively stable over time, implying that 'schooling seems to determine middle- and long-range literacy levels' (p. 14). Similarly, an analysis by UNESCO (1995) established 'universalization of primary education [...] as the determinant factor contributing to the reduction of illiteracy' (p. 33), based on the observation that 'the literacy rate for population age-group cohorts older than 20 years of age tends to remain at more or less the same level as each cohort grows older over time' (Section 3.1, p. 24).

Despite such previous findings, the cohort perspective plays no role in the EFA Global Monitoring Report 2006 (UNESCO 2005), ${ }^{1}$ the last to focus specifically on literacy. The

\footnotetext{
${ }^{1}$ The EFA Global Monitoring Report was the main instrument to assess progress towards achieving the six
} 
magnitude of cohort replacement relative to other contributions to changes in the ALR is not discussed as a matter of course even when 'demographic factors' such as population size and growth are explicitly considered among the 'factors that may (or may not) lead to the reduction in the levels of illiteracy' (Aitchison and Rule 2005, 101-2). The absence of attention to the cohort perspective creates a disconnect between the substantive discussions in the report predicated on the importance of adult education, and, for example, the projections in the very same report that explicitly assume that no literacy gains occur above the age of 19 (Lutz and Goujon 2005).

The mid-term report of UNESCO's Literacy Initiative for Empowerment (LIFE) (Hanemann 2012) does make the dependence of adult literacy on schooling for the young explicit. They note the fact that the ALR is affected by out-of-school children showing up as new adult illiterates, for example. However the report attempts to overcome this limitation by also examining the absolute number of illiterates. While the absolute numbers do provide an important complementary perspective, especially on the practical policy challenges involved, that measure still fails to inform us about actual literacy transitions at adult ages.

The present study re-asserts the need for a systematic analysis of literacy trends as cohorts age. Both Cárceles (1990) and UNESCO (1995) present their cohort comparisons with respect to highly aggregated regions, between only two points in time, and with respect to data based mostly on indirect, (self-)reported census measurement. The present study extends this line of enquiry in various ways. While direct assessments of literacy may still be 'non-conventional' (UNESCO 2005, 179) in practical terms, it is certainly now the 'conventional wisdom' that they are to be preferred over self-reported binary literacy (see, e.g., Carr-Hill (2008), who also provides a general overview of the field of literacy measurement and global trends). The potential difference between reported and tested literacy is known to be potentially substantial (Nath 2007).

Here, I analyse such 'tested' literacy rates in terms of fixed-age cross-sectional and fixedcohort longitudinal trends. For the latter, this study estimates bounds on the distorting effect of differential mortality and migration. In addition, a decomposition is performed to assess the contributions to the changing cross-sectional ALR of literacy conditional on school attainment on the one hand, and changing attainment composition on the other. Finally, the magnitude of

Dakar EFA goals, to which over 160 countries committed themselves in 2000. It was developed by an independent team and published by UNESCO. Each annual edition of the report had an agenda to report progress on each of the six goals, but also to adopt an annual theme, chosen because of its importance to the EFA framework. In 2016, the EFA Global Monitoring Report was replaced by the Global Education Monitoring Report, with a new mandate to assess and report progress on the new SDG on education. 
the contribution of cohort replacement to the target of halving adult illiteracy between 2000 and 2015 is illustrated with a simple projection exercise.

\section{Data and Methodology}

\subsection{Data Sources}

As we have seen, in order to assess the extent to which individual adults are gaining literacy, it is necessary to look beyond the cross-sectional ALR in given years. Ideally, this would involve following the literacy of a fixed group of individuals over time, in a longitudinal study. Unfortunately, such studies are difficult to implement, especially in environments with low literacy. Accordingly, such data are not available at a large scale for a large number of countries. What is possible given available cross-national data is to track the literacy status of the subsamples belonging to a given birth cohort at various ages, the so-called 'pseudo-cohort' approach. For example, if we can observe the literacy rate among 25-year-olds in the year 2000, and 35-year-olds in 2010, any change we observe will be independent of changing schooling of the young. This approach is implemented on two data sources, namely samples from the Integrated Public-Use Microdata Series (IPUMS) and Demographic and Health Surveys (DHS), with a heavy emphasis on the latter.

\subsubsection{IPUMS}

In many countries, data on literacy is collected during censuses. The IPUMS project provides access for research purposes to a large collection of samples of national census data. Of the ten countries that are home to the largest absolute populations of illiterates, census data is available on IPUMS, and includes a literacy measure, for Bangladesh, Brazil, India ${ }^{2}$, Indonesia, and Egypt. However, the time series for Bangladesh and Egypt are rather shorter and therefore omitted in Figure 1.

The advantage of the IPUMS data is that the large sample sizes allow for disaggregated analyses that are otherwise infeasible. Also, in contrast to the DHS, males and females are equally represented. The main disadvantage for the study of literacy, apart from the fact that relatively

\footnotetext{
${ }^{2}$ Strictly speaking, the data for India that are available as part of IPUMS are not census data. Instead, they come from the National Sample Survey (NSS). However, despite being a sample survey, the sample sizes are comparable to the census samples provided for most other countries. In addition, the greater frequency with which the NSS is conducted provides for denser and more timely data.
} 


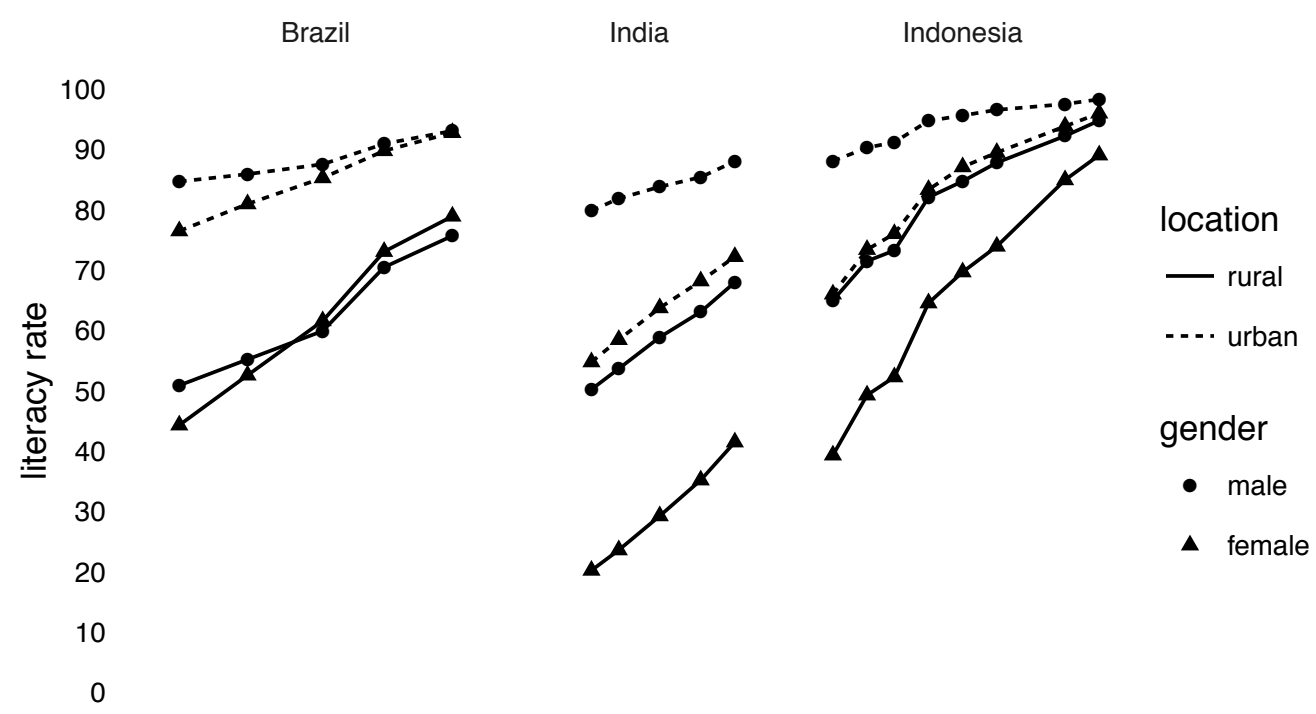

1970198019902000201097019801990200020109701980199020002010 year

(a) Aged 15-49 in each year.

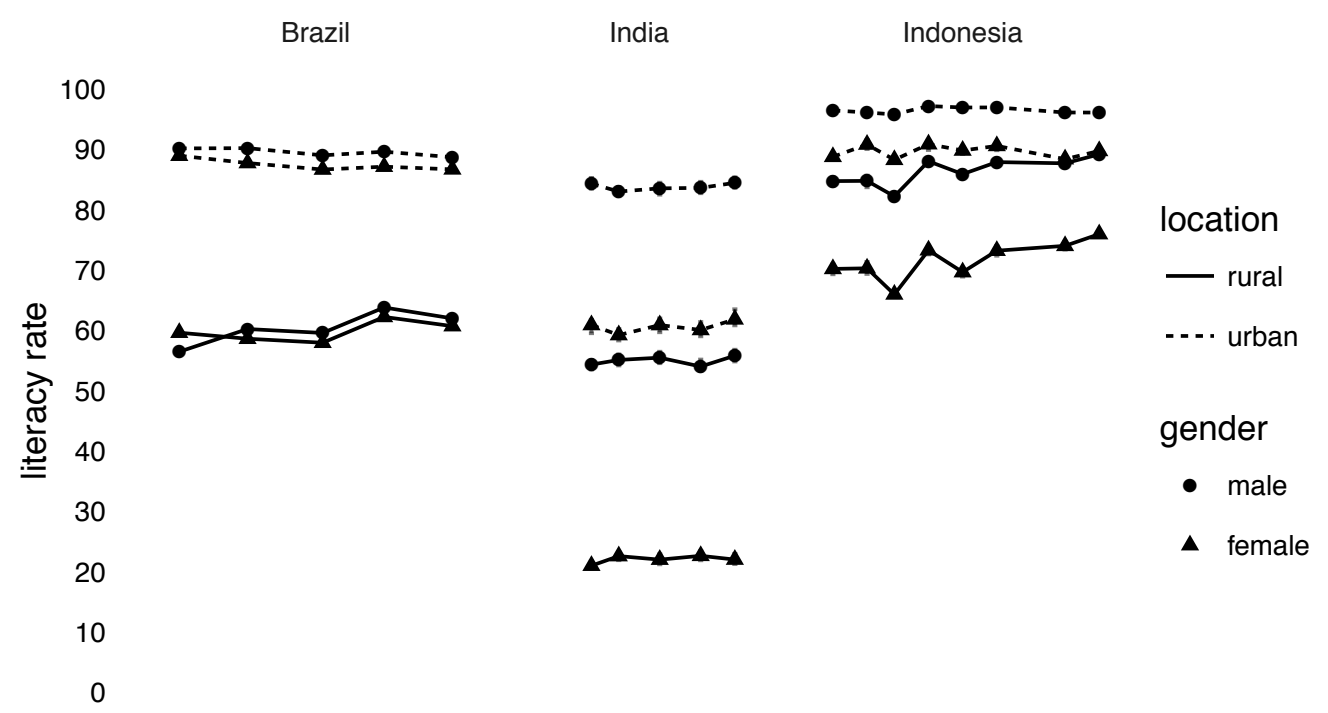

1970198019902000201097019801990200020109701980199020002010 year

(b) Birth cohorts 1950-55.

Figure 1: Female literacy rate, from period (1a) and cohort (1a) perspectives. Bootstrapped $95 \%$ confidence intervals indicated (but barely visible due to their small magnitude). Data: IPUMS 
fewer countries are represented with a literacy variable, is that in census questionnaires, literacy is typically self-reported, or even reported by proxy. This is inevitable when, as is standard census procedure, household members are not interviewed individually, but all information is provided by the household head. In other cases, literacy and educational attainment may be conflated, by assuming that all those who attended school are literate as a result. This assumption potentially disguises declining literacy over age. Such limitations make it unattractive to base an analysis of adult literacy exclusively on IPUMS data.

\subsubsection{DHS}

The Demographic and Health Surveys (DHS) are one of the main sources of household survey information on developing countries that are comparable cross-nationally. They are conducted in a wide range of countries at regular intervals. The present analysis focuses on the more recent waves conducted since the year 2000, and considers two to three waves for 30 countries (14 of which are part of UNESCO's Literacy Initiative for Empowerment (LIFE)). The full list of countries is contained in Table 1.

While not specifically an education survey, the standard DHS questionnaire contains a number of questions on core educational characteristics that are influential covariates for reproductive behaviour, but may also be studied in their own right. In particular, literacy is tested by the interviewer, and is coded at two levels: 'full' and 'partial' literacy.

The DHS literacy assessment takes the form of a relatively simple 'card based' test that may not fully qualify as 'tested literacy' according to the most rigorous definitions, such as Nath's $(2007,121)$, which requires that 'each and every person of the household is given a rigorous test (both oral and written). Instead of a dichotomous assessment, three to five levels of literacy status are identified'. However, the DHS data are still the best available for performing a large-scale cross-national analysis for developing countries. The criticism fully applies here that

'prevailing practices in literacy measurement [...] continue to reflect the [...] "simple and simplistic" definition of literacy. The evolution of thinking - the recognition of the functional purposes of literacy, the complexities and nuances related to the functionalities, and the profound policy and operational implications both for assessing literacy competencies of individuals and communities and promoting literacy effectivelyhas not been reflected in the commonly used and widely accepted measurement 
methodology and its results' (Ahmed 2011, 182).

Unfortunately, there is little we can do in this regard other than to note the caveat, and proceed to analyse the simple measurements we have, that are without practical alternative.

In particular, while the International Adult Literacy Survey (IALS) employed a sophisticated measurement theory (Darcovich 2000), it was limited mostly to high-income countries, apart from being somewhat dated. The more recent and ambitious Literacy Assessment and Monitoring Programme (LAMP) (cf. Ahmed 2011) focuses on developing countries and holds great promise, but it has not yet been deployed at a sufficiently large scale across time and space to provide data for the kind of analysis performed here. In any case, even with the most sophisticated measurement model, questions still remain regarding what exactly is actually being measured (Hamilton and Barton 2000). The DHS literacy data appear to occupy a useful middle ground, combined with the availability of multiple survey waves for a relatively large number of relevant countries.

That literacy is assessed rather than self-reported is a distinct advantage of the DHS data for the analysis of adult literacy trends, as is the large range of countries included and the comparability of the questions. Nevertheless, the DHS data suffer a number of limitations for present purposes. In particular, the main target population is not the general population, but women of roughly childbearing age, namely 15 to 49 . While many DHS samples do include men, not all do, and in all cases the size of the male sample is considerably smaller than that of the female sample.

Moreover, in some societies, questions regarding reproductive behaviour are assumed to be relevant only for married women, and as a result some DHS samples are restricted to ever-married, rather than all women. While weighting schemes exist to remedy this, they would in theory have to be re-calculated for any particular subsample and are provided by DHS only for a small number of standard cases. In principle, the potential bias created with respect to the study of literacy is that if, on average, literate women were to marry at a higher average age than illiterate women, then literacy would increase with age in the sample purely through this selection effect. In practice, the restriction to ever-married women affects only four countries in the present analysis (all in South and Southeast Asia), and these do not deviate from the patterns exhibited by other countries in a way that could be attributed to such an effect.

Note that the fact that there is an upper limit to the age range inherent in the data means 
that the operational 'Adult Literacy Rate' here differs from the textbook definition that would include all adults, without an upper age bound. One implication is that the effect of cohort replacement is amplified. The unrestricted measure would therefore show even less apparent change over time.

\subsubsection{Demographic rates}

Bounding the effect of flows into and out of the sample that differ by literacy status (cf. Section 2.2.2) requires data on mortality and migration rates, disaggregated by sex and age. Both of these are drawn from the most recent available revision of the United Nation's World Population Prospects (WPP). Neither mortality nor migration rates are available conditional on literacy status, or even on educational attainment.

The migration results in particular must be interpreted with caution. Unfortunately, inand out-migration rates by sex and age are simply not available in general. The second-best alternative for present purposes are age-and-sex-specific net migration rates that were estimated for past WPP revisions.

\subsection{Methods}

\subsubsection{Components of the Adult Literacy Rate (ALR)}

If we consider two sets of measurements taken ten years apart, the numeric components entering the calculation of the ALR at the later time can be expressed symbolically as follows:

$$
\mathrm{ALR}=\underbrace{\sum_{a=15}^{24} r_{a} \cdot w_{a}}_{\text {'new' adults }}+\underbrace{\sum_{a=25}^{a_{\max }} r_{a} \cdot w_{a}}_{\text {existing adults, }}
$$

where the $r_{a}$ is the age-specific literacy rate at age $a$, and $w_{a}$ is the share of the overall population currently at age $a$. This effect is illustrated graphically in Figure 2.

Note that only $r_{25}$ and higher actually relate to changes in the literacy status of adults. It is clear that, in addition to such literacy transitions, the overall ALR is also affected by:

- the literacy of 'new adults', i.e., $r_{15} \ldots r_{24}$, and

- the age distribution, reflected in the population weights $w_{a}$. 


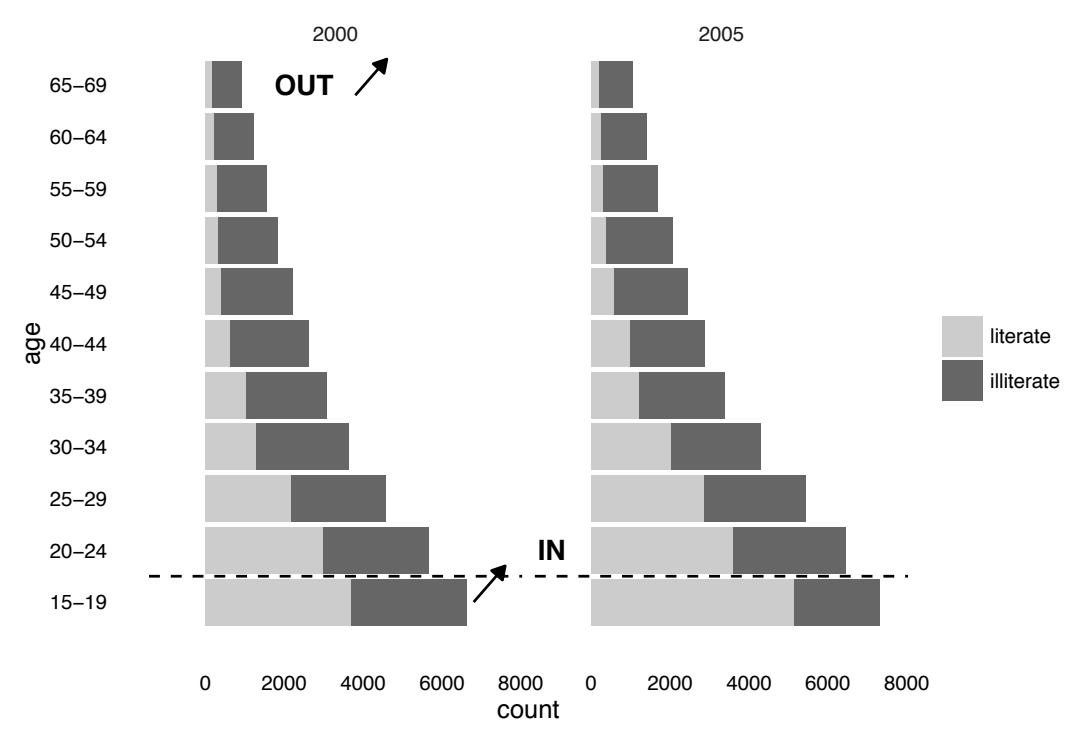

Figure 2: Illustration of the cohort replacement effect.

The latter is determined by fertility and mortality levels, and undergoes a change if either of those determinants change. Assuming that younger cohorts are more likely to be literate on average, this means that, all else being equal:

- a relative decline in old-age mortality will lower the ALR, and vice-versa,

- a relative decline in infant/child mortality will (with a delay) raise the ALR, and vice-versa,

- a decline in fertility will (with a delay) lower the ALR, and vice-versa.

Above, these effects are framed as changes over time. In the same way, different age structures will influence contemporaneous comparisons between countries. While the Youth Literacy Rate (i.e. for the age range 15-24) is meant in part to avoid this issue, it has been shown that an appreciable static age structure effect potentially remains even for such a relatively narrow age range, as is the case for school attendance rates (Barakat, Durham, and Rodrigues Guimarães 2013). The impact of age structure on the overall ALR is typically larger, because the relevant age range is greater and exhibits greater variability. In any case, the Youth Literacy Rate was introduced as an indicator for gender equality in schooling, not to measure 'adult literacy in its own right, as a goal or target' (Robinson 2005, 438).

The established approach with respect to other average population rates is to standardise the age distribution (Siegel, Swanson, and Shryock 2004). A full treatment of age standardisation for the ALR is beyond the scope of this study, as the choice of appropriate standard requires 
some justification, ${ }^{3}$ and because the present focus rests elsewhere. Nevertheless, an illustrative standardisation can give some indication of the potential contribution of pure age composition to levels and changes in the ALR. Standardising all female age distributions according to a model life table (specifically for African countries, with an assumed life expectancy at birth of 60 years and zero HIV prevalence (Sharrow 2013)) results in changes to the ALR of up to 5 points. Arguably this is not negligible for a pure 'accounting' effect that in no way reflects any actual literacy gains, especially given that even many 'successful' countries only see ALR increases of around 10 points over the course of a decade. Nevertheless, in keeping with the currently established definition of the ALR, unstandardised rates are analysed in the following.

\subsubsection{Modeling differential selection}

As previously mentioned, this study involves a pseduo-cohort analysis. Unlike a longitudinal study, the samples at different points in time from among the women of a given birth cohort are not the very same individuals. Apart from sampling variation introduced this way, an important question to ask is whether the composition of this group is changing over time through selection, specifically with respect to mortality and migration. If improvements to health and survival disproportionately benefit the literate, then the adult literacy rate will increase through selection. Conversely, if the literate are increasingly likely to emigrate, the adult literacy rate will decrease, all else being equal.

Here, this selection process cannot be fully modeled with any precision, because the necessary data on mortality by literacy status, or immigration and emigration rates by literacy status, are simply not available. However, as will be demonstrated below, simple bounding exercises can serve as a useful tool in estimating the effects of this selection process.

With respect to mortality, bounds on the possible effect of differential mortality are estimated by simulating the change the ALR would undergo between two points in time if all deaths (calculated from the given overall mortality rates) in a given age group occurred either among illiterates or literates. Where the number of deaths to attribute exceeded the size of the smaller of the two groups, the remaining deaths were drawn from the other group. This is an extreme assumption, of course, but this offers the advantage that the resulting bounds are strict. The ALR may rise as a result of disproportionate mortality among the illiterate, but it cannot possibly

\footnotetext{
${ }^{3}$ In contrast to the school-age range, a 'flat' age structure on the adult population is too far removed from reality to provide a meaningful benchmark.
} 
rise more due to this effect than if only illiterates pass away. This fact is only useful if the observed changes do not always lie within the resulting bounds, which in fact they do not. In fact, it is easy to overestimate the potential distortion due to differential mortality. Even in the countries under consideration here, deaths are still rare events.

The same approach is applied to the flows represented by the net migration rates. Unlike mortality, for migration this does not strictly yield a bound. Even with zero overall net migration, it would in principle be possible for a sizeable outflow of literates to exactly offset a corresponding inflow of illiterates. Nevertheless, it seems a fairly extreme assumption for even the net migration balance to be skewed entirely in one direction or the other.

Note that these bounds are asymmetrical around zero in general, resulting from the fact that the leverage exerted by selective mortality or migration of a given magnitude on the literacy rate depends on the latter's current level. For example, if 97 percent are literate, and 2 percent depart the population, all of whom are literates, the literacy rate changes by less than 0.1 points $(=95 / 98-97 / 100)$. By contrast, if the departures are all illiterates, the literacy rate changes by almost 2 points $(=97 / 98-97 / 100)$.

In principle it seems useful to restrict the analysis to those individuals with at most primary schooling, since, first, graduates of higher levels of schooling are assumed to be literate, and second, because the highest level of formal educational attainment is assumed to remain constant after school-age. However, as the analysis shows, the latter assumption may not hold. And if it does not, examining the literacy rate among the poorly-schooled in isolation may be misleading, because it would decline if the literate increase their attainment. Accordingly, the following analyses make use of the attainment information where appropriate, rather than examining only those with at most primary schooling throughout.

\subsubsection{Decomposition into attainment and conditional literacy components}

The change in the ALR due to the entry of young adults into the calculation arises because these typically enjoy higher levels of literacy than the older adults that left, or in the case of a capped age bracket, 'aged out of' the calculation. A relevant question is how much of this effect results from an expansion of school participation and attainment, and how much from improved literacy outcomes among graduates of a given school level.

The difference in average literacy between the 'new adults' and the ones they are replacing 
who have 'aged out of' the age bracket capped at age 49 can be expressed as the sum of three components: 'composition', i.e., differences in educational attainment; 'rates', i.e, differences in literacy conditional on attainment; and a term capturing the interaction of the first two. Formally:

$$
\begin{gathered}
\Delta L=L_{\text {in }}-L_{\text {out }}=E_{\text {in }} \cdot R_{\text {in }}-E_{\text {out }} \cdot R_{\text {out }} \\
=\underbrace{\left(E_{\text {in }}-E_{\text {out }}\right) \cdot R_{\text {out }}}_{\text {Composition effect }}+\underbrace{E_{\text {out }} \cdot\left(R_{\text {in }}-R_{\text {out }}\right)}_{\text {Rates effect }}+\underbrace{\left(E_{\text {in }}-E_{\text {out }}\right) \cdot\left(R_{\text {in }}-R_{\text {out }}\right)}_{\text {Interaction }},
\end{gathered}
$$

where $L$ is the literacy rate, $E$ is a vector of shares at different levels of attainment, $R$ is a vector of conditional literacy rates for each attainment level, and multiplication is the standard scalar product $^{4}$.

This method was devised concurrently by Blinder (1973) and Oaxaca (1973) for investigating wage differentials and discrimination, and still remains 'a standard tool in the toolkit of applied economists' (Fortin et al 2010,1). While there are various ways of attributing the interaction term to either of the first two, or - equivalently — of defining the 'reference' group, in the present result the elementary results are sufficiently clear-cut to forego such complications.

\section{Analysis and results}

\subsection{Cross-sectional versus cohort perspectives on adult literacy}

The central result of this study is the difference between trends in cross-sectional period literacy for a given age group compared to the literacy of a given cohort. These comparisons are shown in Figure 1 based on IPUMS data, and again in Table 1 (in the Appendix) based on DHS data from more countries. The key column (5) from that table, namely the difference in the apparent growth of adult literacy between the cohort and period perspectives, is also shown graphically in Figure 3.

The cohort being tracked in Table 1 showing the DHS results is the one aged 20-34 at the first survey in the respective country. This age range ensures that the older members of this cohort do not fall outside the DHS sample range by the time of the final survey. If more country samples were restricted to ever-married women, raising the lower boundary to 25 years may help reduce some of the resulting bias, but at the expense of the sample size. As mentioned above, only a small minority of countries in this study are restricted to ever-married women, however.

\footnotetext{
${ }^{4}$ I.e., $A \cdot B=\sum_{i=1}^{n} A_{i} B_{i}=A_{1} B_{1}+A_{2} B_{2}+\ldots+A_{n} B_{n}$
} 
In summary: looking at the adult literacy rate based on a fixed age bracket, it seems that most countries are on a trajectory of slow, but definite improvement over time. With respect to females, and the full literacy measures, for example, 19 out of 30 countries exhibit a significantly positive period growth rate, and none a significantly negative one. However, these apparent gains essentially disappear from a cohort perspective. Only 5 countries exhibit significant growth from this perspective, and at significantly lower rates (cf. Figure 3), while cohorts in 10 countries suffered significant literacy losses. In other words, measurable gains in literacy at adult ages are the exception rather than the rule. In most countries, literacy among these cohorts appears to stagnate or even decline over time and age. The increase in overall adult literacy is driven almost entirely by the replacement of older cohorts with low literacy, who drop out of the age bracket that enters the calculation of the adult literacy rate, by younger cohorts with higher literacy that newly enter the calculation.

On the IPUMS data, we can see that the above conclusion holds for both men and women, and independently of urban or rural residence. While the overall pattern for males is the same as for females, in the DHS data the estimation intervals are much wider for men due to the smaller sample size. Wide enough, in fact, to render the results formally inconclusive. We can therefore only tentatively note that there is no evidence to suggest that the pattern for males is different, but that the male sample does not add any further information to the analysis. Accordingly, all further analyses conducted below are restricted to the female sample.

Nepal stands out as an outlier. Not only does it post the most rapid improvement in the female period ALR of the countries analysed here, it is also the only one where such a strong and sustained improvement is confirmed at the cohort level over three survey waves. While the 2001 survey was restricted to ever-married women, the latter two both include all women in the target population, so the marriage bias does not account for the later growth. Moreover, it is not intuitively clear how problems of representativeness in the samples could account for this observation: during the early survey wave, the ongoing conflict made access to some rural areas difficult, but this would bias the results in the direction of a spurious decline in literacy, if urban areas were overrepresented in the early wave(s) but not the latest wave. Interestingly, an auxiliary analysis shows that this cohort gain is not mainly due to improved literacy among the poorly schooled, but due to an increased share of those with at least primary schooling. This is a curious result, because in general, formal school attainment is even more stable beyond 


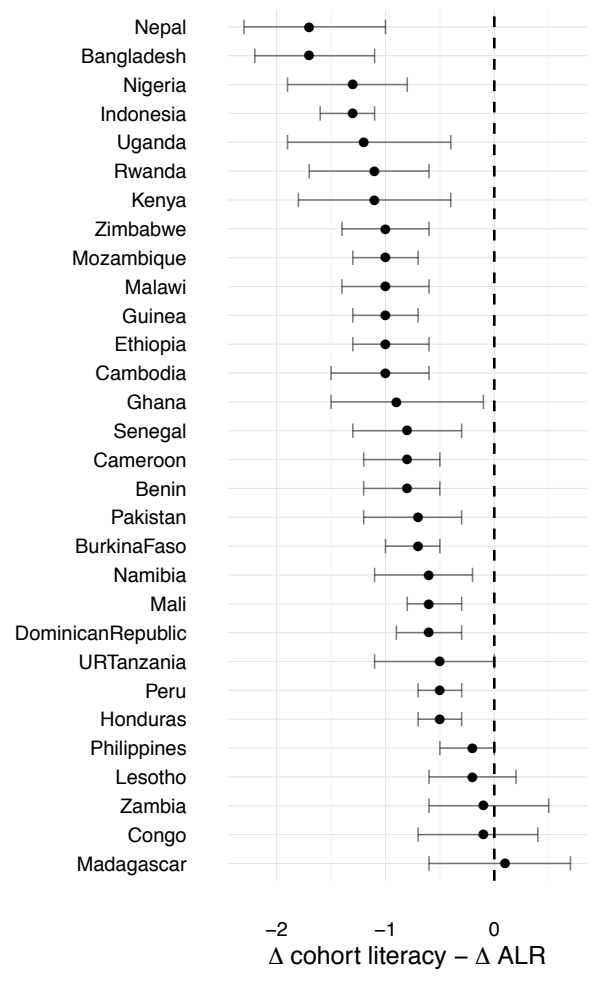

(a) females

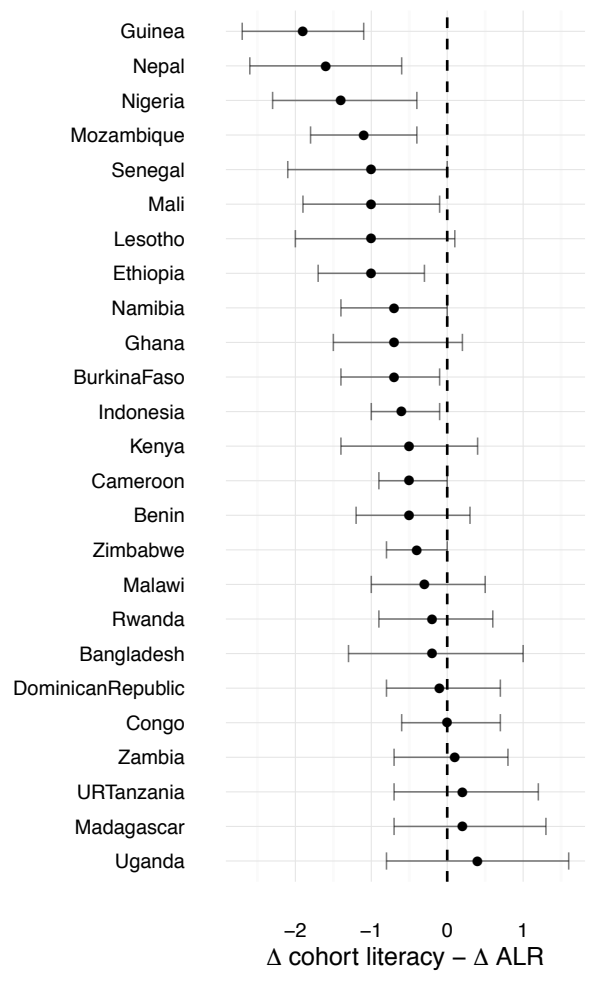

(b) males

Figure 3: Difference between literacy trend over time (average annual percentage point change) from a cohort relative to the period perspective. Based on Table 1.

school age than literacy is. Even adult literacy programmes that are considered equivalent to a primary school graduation are often not counted as such for the purpose of recording formal educational attainment. Indeed, at least in 2006, links between literacy programs and formal schooling were not institutionalised, and reports about the former's graduates moving into formal schools referred only to girls, not adult women (Acharya and Koirala 2006). If these results can be validated against other information on large-scale adult education programmes in Nepal, they suggest that these may have succeeded to a greater extent than is often the case. ${ }^{5}$

Having acknowledged that some improvements in the literacy of adult women seem to have been achieved in Nepal, it is nevertheless important to point out that even in this case, these improvements account for only a fraction of the gains in the cross-sectional adult literacy rate. While the adult literacy rate increased by around 25 percentage points between 2001 and 2011, the 1967 to 1981 birth cohorts improved their literacy only by around 9 percentage points during

\footnotetext{
${ }^{5}$ The DHS itself contains some limited data on participation in adult literacy programmes. These are arguably inconclusive with respect to whether their success in benefitting their participants. But the 'inverse' question more relevant for present purposes, namely whether the cohort literacy gains that are apparent in the sample can be attributed to programme participants can be answered in the negative. The apparent gains among Nepali women remain enigmatic, therefore. [ANALYSIS ATTACHED TO THE END OF THE DOCUMENT FOR REVIEW PURPOSES.]
} 
that time, the remainder resulting from the changing composition of the adult population.

As mentioned in Section 2.1.2, the DHS literacy variable distinguishes two thresholds: full and partial literacy. The above discussion was based on the more stringent definition, but examining partial literacy instead does not significantly change the conclusions. This is unsurprising, given that across all countries, among the subsamples in question, the fully literate outnumber the only partially literate by about 8-to-1. In other words, literacy tends to be an 'all or nothing' status in the data under consideration, rather than a skill that many make limited progress on but only few master.

Both positive and negative observed changes from a cohort perspective are, on average, smaller in magnitude when the partially literate are included among the literate, suggesting that movement between partial and full literacy is more common than movement out of complete illiteracy. In principle, this phenomenon either occurs because of partially literate women improving their skills and literate women relapsing into partial literacy (a problem affecting even initially effective adult literacy schemes (Guodong and Zhupeng 2003)), or because of measurement error around the boundary between full and partial literacy. The fact that the implied transitions between partial and full literacy appear to be roughly equally likely in either direction may point towards the latter explanation. Unfortunately, the present data do not allow for disentangling these effects empirically, which would require longer time series.

To the extent that lowering the literacy threshold does change the results for individual countries, it relativises some of the largest increases and declines in terms of full literacy. In Cambodia and Uganda, for example, women appear not to have dropped out of literacy completely, but merely to have experienced a decline in the level of their literacy skills. Conversely, in Pakistan, Congo, and Zimbabwe, increases in the number of 'newly literates' may have mostly been drawn from among those who already possessed some literacy previously. Finally, Bangladesh has actually made large improvements of sorts, second only to Nepal, but limited to increasing partial literacy. The implication may be that it is effectiveness that is lacking, rather than effort.

\subsection{Bounding potential selection effects}

Again with reference to the cohorts aged 20-34 at the first survey in each country, Figures 4 and 5 display the results of the bounding exercise, separately for low and high HIV/AIDS prevalence 
countries. ${ }^{6}$ This graph is to be read as follows: the triangles indicate the actual observed (annual) change in cohort literacy; the squares indicate what the maximal distortion would be if all deaths were happening to the illiterate or literates respectively, and the circles indicate the change that would happen if the net migration balance were strictly biased towards increasing the share of illiterates or literates respectively. Like all of the remaining analyses, this is limited to the female subsample and the 'full literacy' measure.

For the low HIV/AIDS prevalence countries (Fig. 4) we may assume that in reality the right-hand side of the mortality bound is the more relevant, corresponding to the assumption that mortality is higher among the less educated and therefore tends to create an upward drift in adult literacy along cohort lines. For the bulk of low HIV/AIDS countries, the literacy change actually observed is marginal, and it is unlikely that either mortality selection is offsetting a large number of negative literacy status transitions or, conversely, that migration selection is offsetting a large number of true positive literacy transitions. At the bottom end, with few exceptions, the significant declines that there are cannot be attributed to the emigration of literates, unless we are willing to make extreme assumptions about migration behaviour that exceed even the strictly one-sided net migration bias assumed here. At the top end, where the apparent literacy gains are located, we see that in the case of Pakistan and Nepal, their gains could not possibly be attributed to mortality selection.

In the high HIV/AIDS prevalence countries, there is greater uncertainty about the direction of a mortality selection effect by education. Some evidence suggests that with respect to HIV/AIDS, the usual negative educational gradient is frequently reversed. That is, more educated individuals may be at higher risk (Fortson 2008). The implication is that AIDS mortality may select in the opposite direction than assumed above, and decrease the apparent literacy rate. Firstly, however, the empirical evidence is actually mixed, and the relationship may be changing over time (Hargreaves et al. 2008) or over the course of the epidemic (Iorio and Santaeulàlia-Llopis 2011). Moreover, such studies typically operationalise the educational gradient in terms of attainment or years of schooling, not literacy. Even if those with more schooling experienced a higher risk of being infected with HIV or developing AIDS (which by itself does not automatically mean they would suffer a higher mortality), it does not necessarily follow that among the unschooled the literate have a higher risk than the illiterate. And even if they did, it would not necessarily follow

\footnotetext{
${ }^{6}$ With a threshold of 5 percent overall adult prevalence as reported in WHO's Global Health Observatory Data Repository
} 


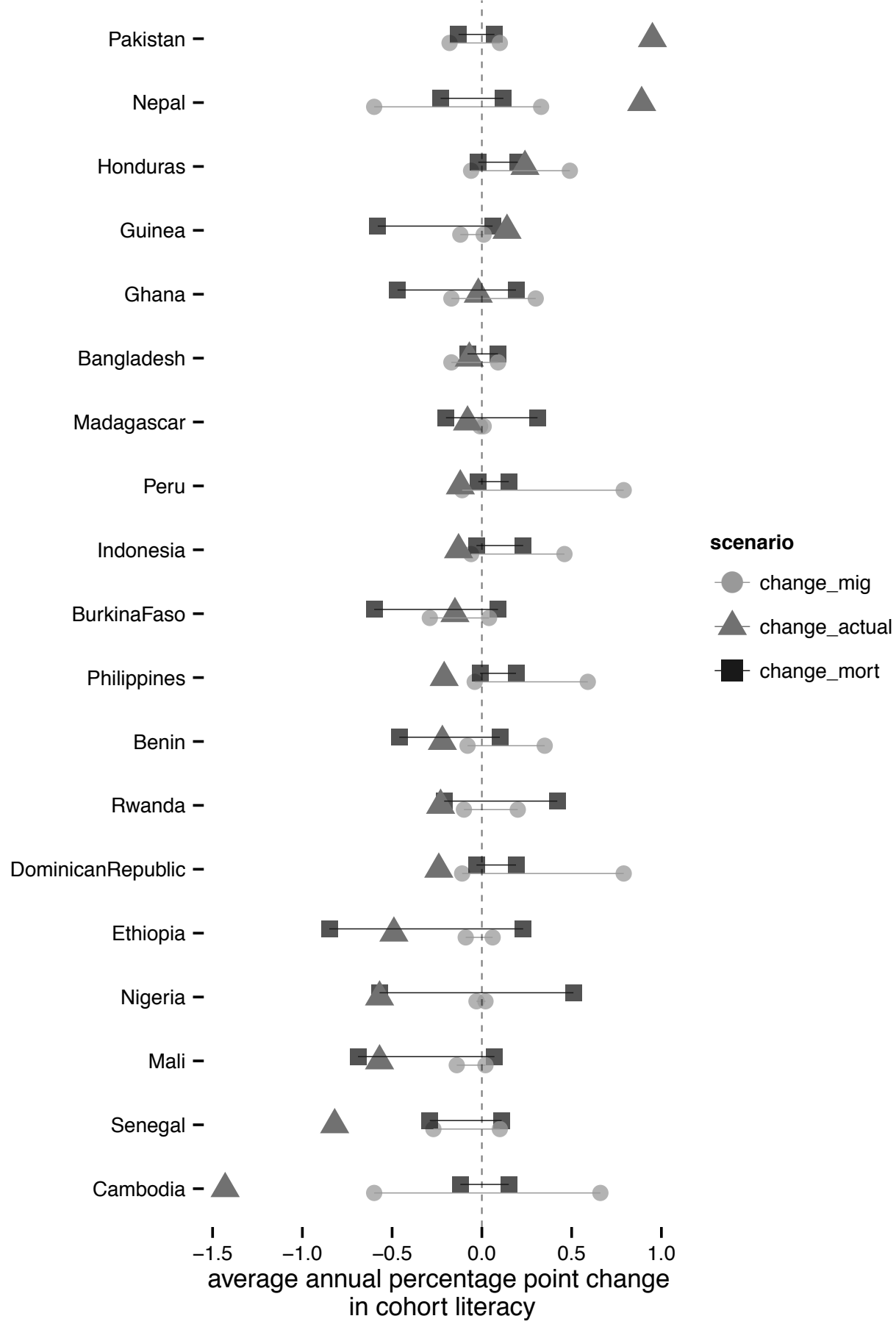

Figure 4: Bounds on the impact of mortality and migration on female cohort literacy change (see text for details). Data: DHS (literacy data) and WPP (mortality and migration data) 


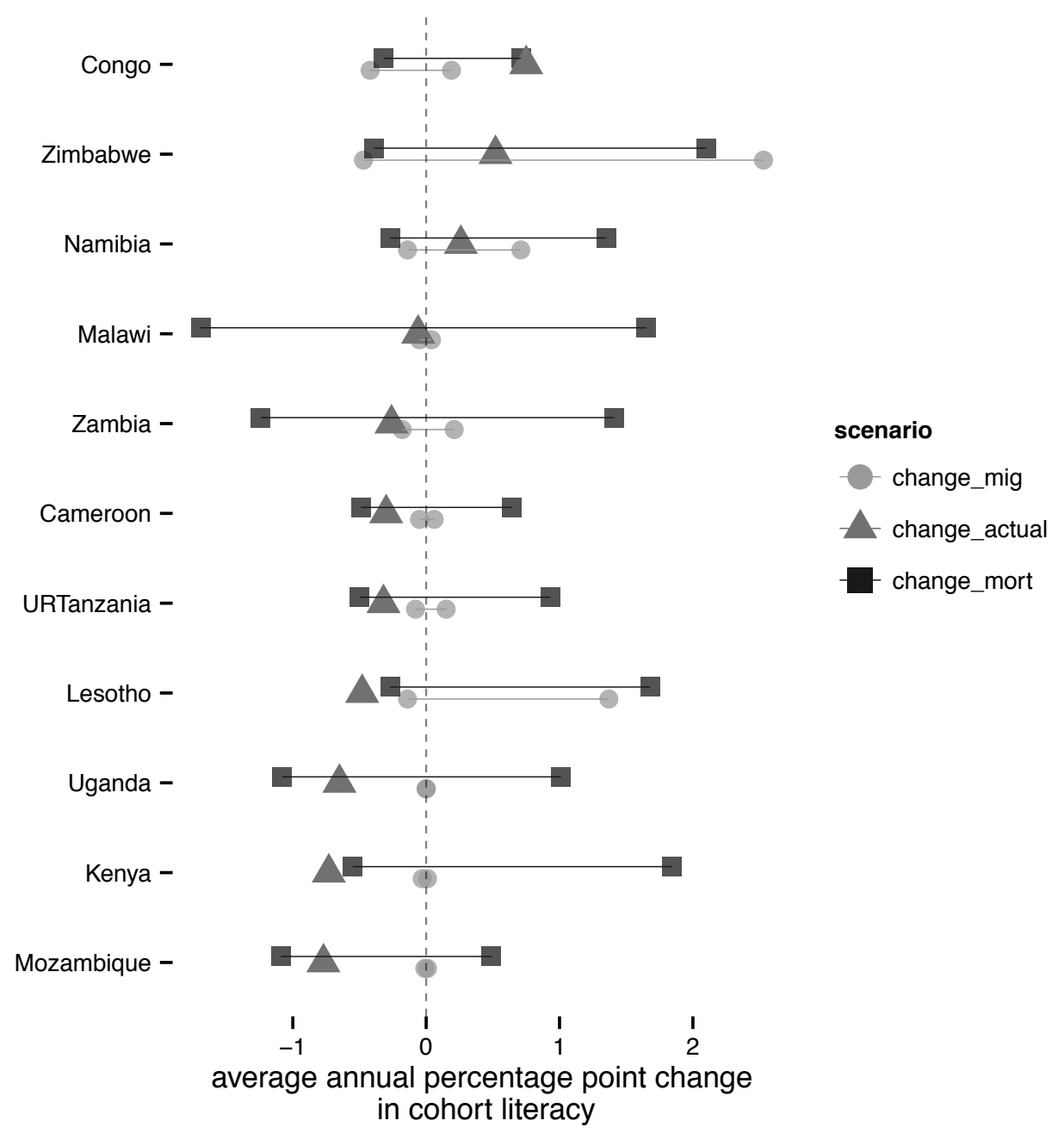

Figure 5: Bounds on the impact of mortality and migration on female cohort literacy change, high HIV/AIDS prevalence countries (see text for details). Data: DHS (literacy data) and WPP (mortality and migration data)

that this would offset their other health disadvantages to the point of reversing the overall literacy gradient with respect to mortality. Moreover, in a health system strained by the burden of AIDS, it seems likely that other inequalities would be exacerbated. Indeed, even where HIV/AIDS prevalence is positively related to school attainment, the educated still enjoy higher survival rates conditional on infection. In addition, the apparent literacy decline over age correlates poorly with HIV/AIDS prevalence. Some high-prevalence countries such as Malawi or Namibia have virtually no apparent decline, and some of the biggest declines are in countries with relative low prevalence of HIV/AIDS, such as Senegal or Cambodia. In sum, while in high-prevalence countries the mortality bound is even less likely to be strict than without HIV/AIDS, there is insufficient evidence to assume it actually reverses the relationship. It seems prudent therefore 
to consider the bounds in both directions.

Interpreted in that way, the results show that, as for low HIV/AIDS prevalence countries, mortality selection cannot serve as a general explanation for the observed declines in literacy. In Lesotho and Kenya, even if the education-mortality relationship were completely reversed this would not induce a literacy decline as large as the one observed. At the other end, we can see that the status of the apparent literacy gains in Zimbabwe and Namibia is different from those in Pakistan, Nepal, and, to a lesser extent, Congo, in that the latter but not the former fall outside the range of apparent literacy change that could conceivably be due to mortality selection. In other words, in Zimbabwe and Namibia, selective mortality cannot be ruled out as an explanation for the modest increases observed.

In sum, on the one hand there exist examples both of positive and of negative changes in literacy over age from a cohort perspective that are not easily explained as resulting from selection effects; On the other hand, most countries saw only small changes in literacy for the cohorts examined, and the potential for larger changes to have been offset by selective attrition is fairly limited.

\subsection{Quantity versus quality of schooling}

We already know that most of the apparent gains in the ALR are due to more literate cohorts moving up into the adult age bracket. In the case of this research, where the adult literacy rate is calculated for ages 15 to 49 , in a hypothetical example with two survey waves ten years apart, those aged 40-49 at the first point in time will be replaced by those aged 15 to 24 at the second. If the latter are more literate than the former, a relevant question is whether this is because they benefitted from more schooling, or whether at a given level of schooling they experienced better literacy outcomes. In other words, did the young receive more schooling, or better schooling? ${ }^{7}$ As discussed in the methodology section, one way to study this issue is to perform a decomposition that implicitly simulates how the adult literacy rate would have changed if either the attainment

\footnotetext{
${ }^{7} \mathrm{~A}$ different question concerns the possibility of a quantity-quality trade-off, in other words the 'evidence that the surge in numbers enrolled in primary education has led to a disastrous drop in quality' (Molteno et al. 2001). Since at least for countries with only marginal literacy change at adult ages we can estimate the literacy of older cohorts when they left school from their literacy at the age when they were observed, this trade-off could be examined directly. Taken at face value, doing so suggests that literacy among school graduates did not decline as schooling expanded, and this conclusion is consistent with independent findings on other data elsewhere (Spaull and Taylor 2015). However, in light of contradictory findings, and given the approximate nature of such an analysis, this only qualifies as 'absence of evidence' (of a quantity-quality trade-off), not 'evidence of absence', and is therefore omitted here. [ANALYSIS ATTACHED TO THE END OF THE DOCUMENT FOR REVIEW PURPOSES.]
} 
distribution, or the distribution of literacy conditional on attainment, were identical for the cohorts leaving and entering the calculation of the indicator. The result is shown in Figure 6 for those countries that have only marginal literacy change at adult ages, in order to focus fully on the effect of cohort replacement. It is evident that the improved attainment profile of the young generation in all cases makes a much more important contribution to raising the adult literacy rate than changes in literacy conditional on attainment do. In other words, it is the improved 'quantity' of schooling that accounts for increasing adult literacy.

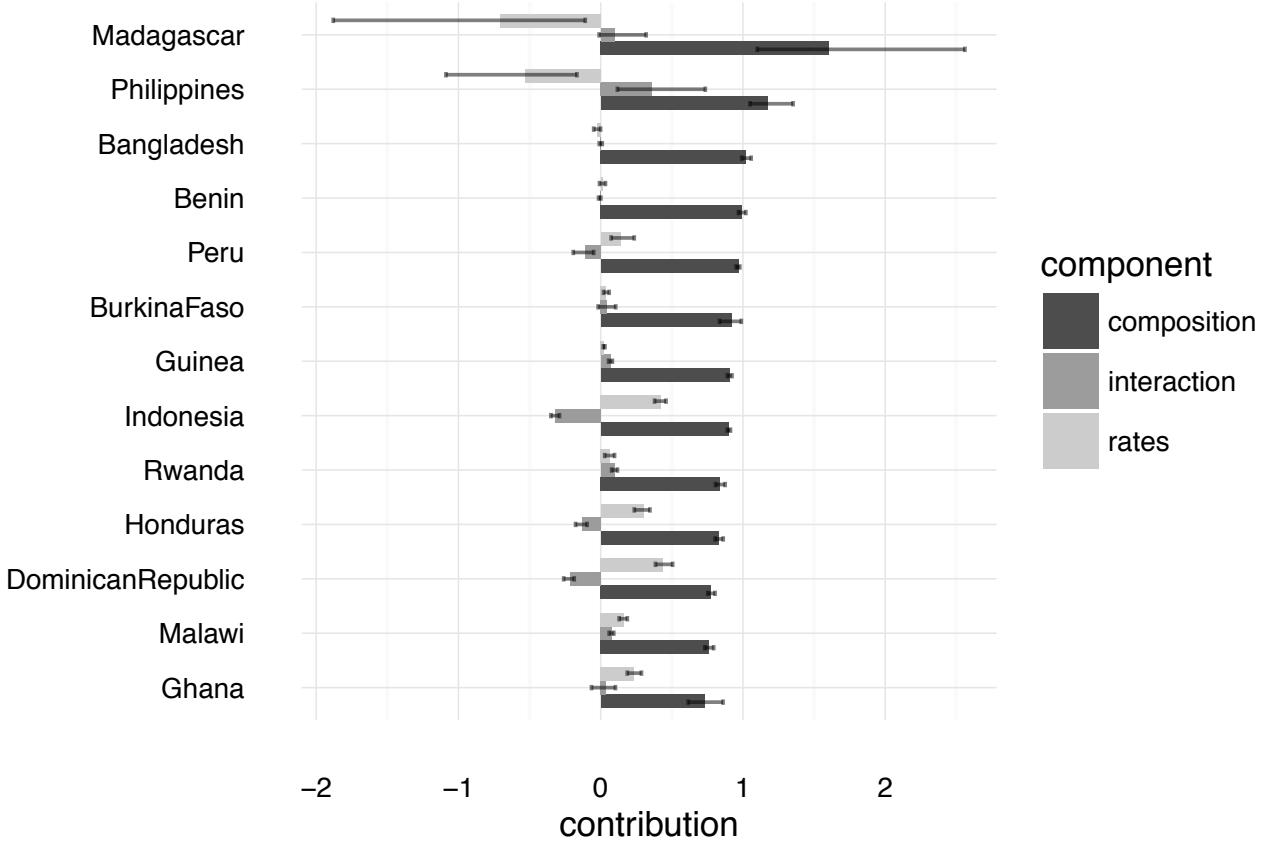

Figure 6: Contribution to change in female $\mathrm{ALR}_{15-49}$ if the young individuals entering the 15-49 age bracket share the same school attainment profile as the older group they are replacing, or the same literacy rates conditional on attainment. Blinder-Oaxaca decomposition, with observed change normalised to 1 . Only countries with minimal cohort literacy drift shown. Data: DHS

\subsection{Projections}

The changing age structure of the adult population can be projected with a reasonable amount of accuracy in the medium term. Indeed, for the first fifteen years, the new entrants into the adult $15+$ age bracket are already alive in the baseline year. A natural question in light of the preceding sections is therefore how the conventional cross-sectional ALR might be expected to change in the future, even in the absence of literacy gains at adult ages.

Possibly more interesting in the context of international development targets than an unconditional projection is the question to what extent the target of Universal Primary Education, 
together with population dynamics, implies for progress towards the adult literacy target of halving the share of illiterate adults.

A full-blown literacy projection model would require the specification and justification of a great number of detailed assumptions regarding issues such as mortality differentials by literacy status. Here, a very simple projection is presented as a first-order approximation, with its implications for the overall ALR displayed in Figure 7. Using the UN population projections, the age-specific literacy rates at adult ages prevailing in the year 2000 were assumed to remain constant along cohort lines. For the child cohorts, their literacy by age 15 conditional on attainment is assumed to either: a) remain constant (Panel 7a), or b) to linearly increase to 100 percent by 2015, reflecting the joint effect of achieving Universal Primary Education and universal literacy among primary graduates by that year (Panel 7b).

Since the trajectories in Figure 7a assume no improvements in the schooling and literacy of children and young adults, the changes seen are entirely due to age structural dynamics. Since this is an extreme underestimate of likely dynamics, it is unsurprising that the effect is modest in most cases. Nevertheless, the highlighted countries demonstrate that even pure age dynamics can relatively quickly lead to large differences between countries starting from similar ALRs.

Three observations can be made with respect to the EFA scenario (Figure 7b). First, thatgiven the stated aim of achieving UPE - some countries would have reached EFA target 4 of halving the share of illiterate adults within three years of the 2015 milestone even without any targetted adult literacy policy. Secondly, that by contrast, relying only on improved schooling, other countries would in 2015 still have been ten years away from meeting the adult literacy target. Thirdly, note that this spread in timing is not closely linked with starting level of adult literacy. In other words, there are 'early' and 'late' examples among both countries with relatively high and low levels of illiteracy. This reflects the fact that the improvement induced by cohort replacement depends on a country's recent fertility and schooling trends, which exhibit a large variation. This is highlighted by the example of Cambodia and Uganda, where the cohort replacement effect alone, still without any adult literacy interventions, even results in a cross-over of the ALRs under the UPE scenario. Because Cambodia has already experienced a marked fertility decline, the weight of the better-schooled young cohorts in pushing up the ALR is reduced. This contrasts starkly with Uganda, were the young cohorts are so much larger that their literacy levels begin to dominate the overall ALR much more rapidly. 


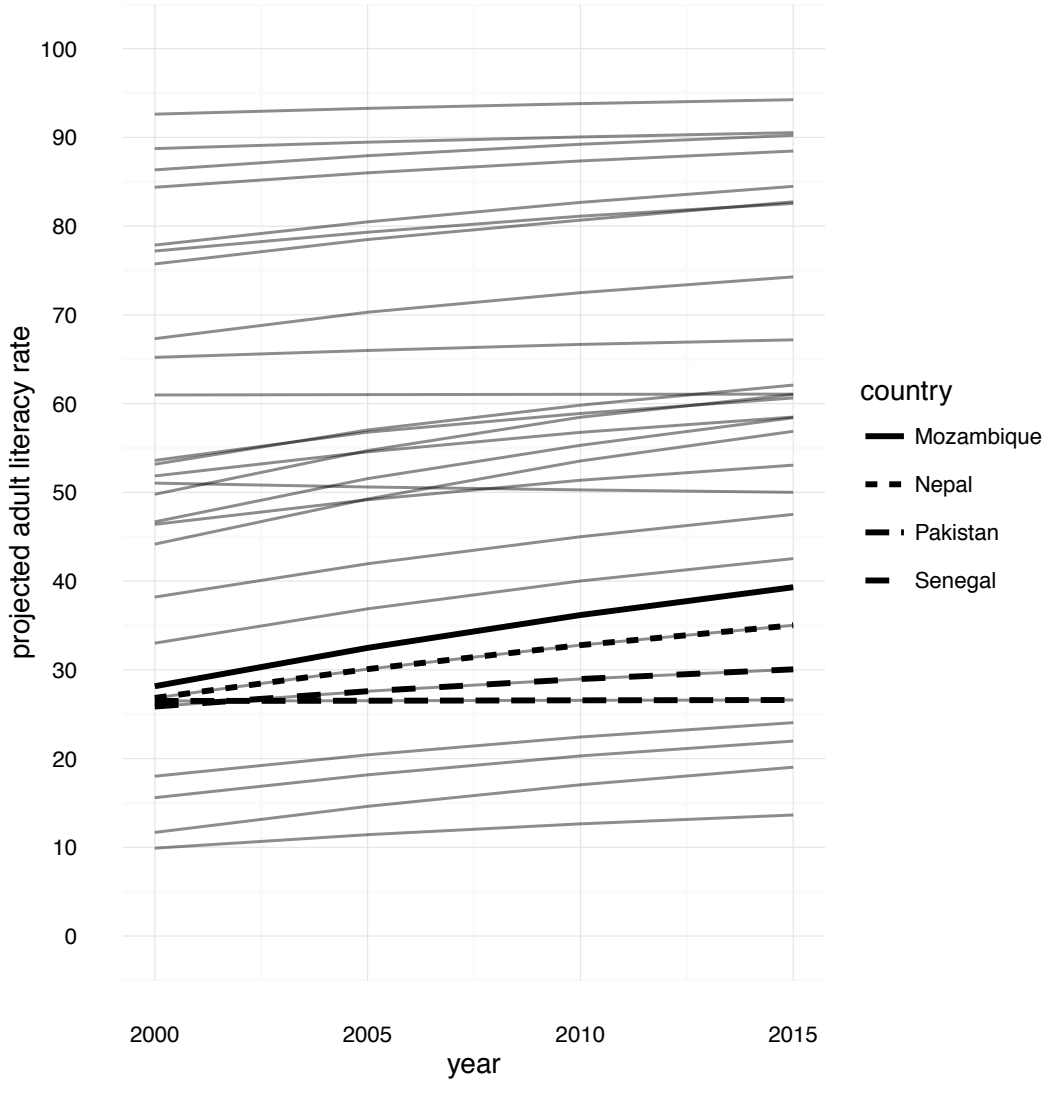

(a) Constant attainment and attainment-specific literacy scenario.

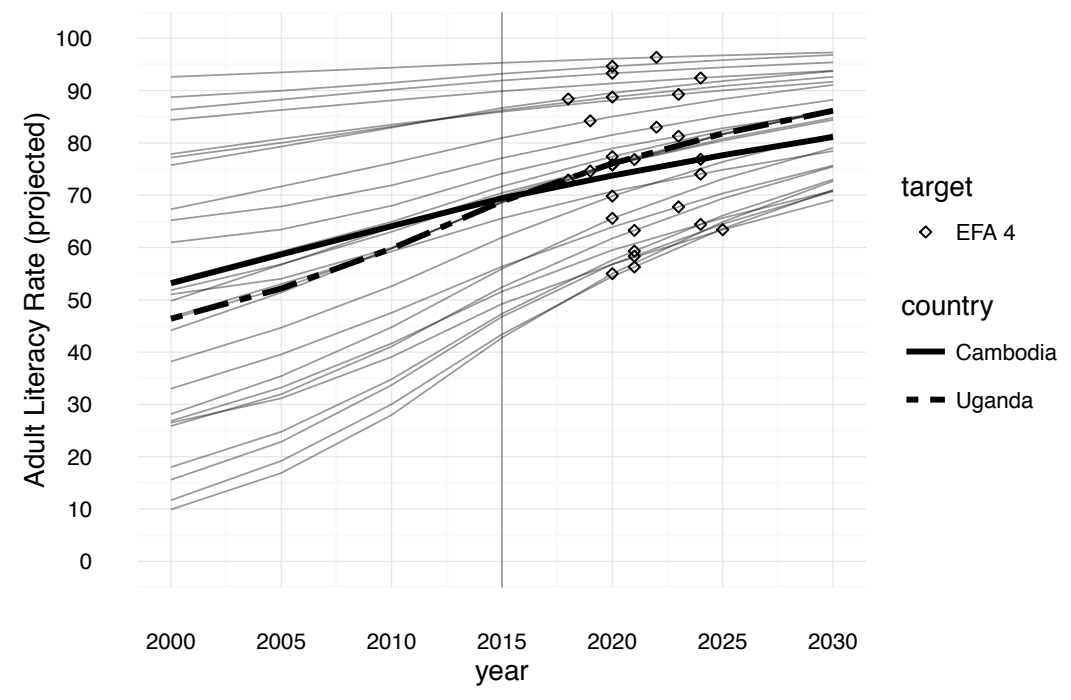

(b) Universal Primary Education (UPE) by 2015 scenario.

Figure 7: Counterfactual projection of the female Adult Literacy Rate based on 2000 baseline data for two scenarios. (a) assuming the achievement of Universal Primary Education by 2015 and the literacy of primary graduates converging from their 2000 level to 100 percent by 2015 . Points mark the year in which EFA goal 4 of halving adult illiteracy would have been achieved under this scenario. (b) Assuming no improvement in attainment or literacy conditional on attainment. 


\section{Discussion and conclusions}

The present results show that changes in the literacy of a given pool of adults differ substantially from the trends suggested by the standard cross-sectional indicator called Adult Literacy Rate (ALR). The modest gains in the ALR seen in most countries in this study were in most cases achieved almost exclusively through better schooling for the young, not the acquisition of literacy skills by illiterate adults (neither measured nor self-reported). This confirms, on a more rigorous footing, the claim that ' $[\mathrm{t}$ ] he contribution of adult literacy programs in increasing literacy rates in various countries thus far has been marginal [and that they] probably will not contribute significantly' (Abadzi 2004, 1-2) to reaching the Dakar literacy goal (the target date for which has now passed), and conversely, that 'future trends in the illiteracy of the adult population largely depend on trends in access to and participation in primary education' (Carr-Hill 2008, 39), much like in the past, for example in China, where 'the drop in illiteracy of the new parental generations [in China] was brought about by the widespread access to basic primary education' (Banister \& Zhang 2004, 38). It may be true 'that the history of literacy acquisition does not coincide with the history of formal schooling' (Limage 2005, 2), but it seems that its future will. In other words, 'learning at the bottom of the pyramid' (Wagner and Castillo 2014) is at the same time largely about 'learning at the bottom of the age pyramid'.

The importance of carefully quantifying this effect is underlined by the fact that the present analysis also shows that its power has been overestimated on occasion. When Carr-Hill et al. $(2010,436)$ qualify the notion that 'in the long-term one could argue that providing $100 \%$ primary schooling will eliminate adult illiteracy in the future', they do so by pointing out that such school expansion is unlikely to be achieved. However, the results in Section 3.4 justify a nuanced view: relying entirely on UPE might take some countries most of the way towards halving adult illiteracy, but eliminating it entirely through schooling for the young would take many decades even under the most optimistic scenario with respect to school expansion.

The present finding of little population-level evidence of literacy acquisition at adult ages does not amount to a 'negative impact evaluation' of adult literacy programming in specific cases, much less in general. To begin with, several countries with anecdotally successful mass literacy campaigns are missing from the analysis. Even among the countries included, data on actual participation in literacy programmes was sparse. Where available, they do not seem to allow the attribution of achieved literacy gains to participation in such programmes. But to conclusively 
answer the reverse question, i.e., whether a particular programme 'worked', would require a different kind of analysis - and a different kind of data. The present results do not necessarily contradict the existence of highly successful small-scale 'literacy projects', as opposed to national 'literacy campaigns' (Maruatano 2008). Indeed, 'finding ways to "scale up" critical literacy initiatives to national level while retaining a focus on local participation, diversity and minority interests is still a challenge' (Hamilton \& Pitt 2011, 597). Moreover, not all of the broader possible effects of literacy campaigns listed by Bhola $(1984,258-9)^{8}$, for example, are necessarily conditional on successfully meeting the narrower outcome of literacy acquisition. Blunch notes (2012, p. 115) that the fact that 'participants [in adult literacy programs] often learn skills other than literacy and numeracy, including those related to health, income generation, and civic education' may be sufficient to make the programs cost-effective overall 'even if programs are not successful in promoting literacy and numeracy skills per se'.

Further regarding costs, contradicting the claim that 'educating adults is usually less effective and more costly than educating children' (Durgunoglu et al. 2003, 18), Carr-Hill et al. (2010, 436 ), in a comprehensive review of cost analyses, note that 'if we assume that four years are needed to make a child literate in primary school, then the cost of making a single adult literate is considerably less than educating a child through primary school'. While primary schooling for all children should be funded as a matter of course, this finding does suggest that 'in terms of inter-generational equity, it would seem obvious that one should invest in adults' (Carr-Hill et al. 2010, 436) when it comes to spending that is dedicated to reducing adult illiteracy.

In addition, some adult literacy programming — and perhaps the most successful — is directed at illiterates in their late teens or early twenties. While these participants are technically adult, it is difficult or even impossible to disentangle the outcomes of such programmes from those of (delayed) formal schooling, especially in the absence of true longitudinal data. However, this is unlikely to be the main explanation for the patterns observed, given the finding that gains in ALR due to increasing youth literacy are mostly due to higher formal attainment. Nevertheless, some successes of literacy programmes for young adults may have been obscured.

At the global level, the new, holistic, literacy paradigm had already taken over the international

\footnotetext{
${ }^{86}$ national integration and, particularly, integration of national minorities; the emergence of new national identities and new political cultures; cultural pride and respect for heritage; political re-socialization; the abolition of class structures and progress towards the equality of women and men; modernization of economic institutions and increase in productivity; better health of the people, including decreases in infant mortality and greater intake of high protein foods; higher levels of information consumption and participation in local institutions; and scholarization of children'
} 
discourse (Mpofu and Youngman 2001) during the period that gave rise to the data analysed here. However, the present results do not serve as evidence that the new paradigm achieved equally little as the 'traditional', functional literacy paradigm, because, the latter still dominated actual national policy-making. In any case, note that the effect demonstrated in this study, that changes in average literacy of adults reflect population dynamics as much as adult literacy acquisition (and typically more so), pertains regardless of how exactly literacy itself is measured at the individual level. This is true even if the underlying literacy measure were continuous, and even if the 'true' literacy status were somehow known.

The main conclusion, then, is not that there are no changes in literacy at adult ages in general, although it is disheartening that true gains appear to be so hard to find, confirming findings from the program evaluation literature (Abadzi 1994; Ortega \& Rodríguez 2008; Blunch \& Pörtner 2011). The analysis shows that substantial changes in cohort literacy can indeed be observed in some cases, changes that are extremely difficult or even impossible to explain as an outcome of selective attrition. Since it is evidently possible for literacy to be gained at adult ages, we should continue to seek ways to understand these dynamics and to encourage such gains.

This remains true even if significant progress towards adult literacy goals as measured by the ALR could be made by school expansion alone. But universal primary education and adult literacy should not stand in competition. That we should not 'leave the eradication of illiteracy to primary education' (Bhola 1984, 256), and that instead, 'nations should develop policies to expand both primary and literacy education' (Maruatano 2008, 747) is a recurring exhortation spanning several decades. Pragmatically, not only is primary schooling crucial in reducing adult illiteracy in practice, but adult literacy can also make an important contribution to increasing school participation (Chudgar 2009). Perhaps more importantly, focusing exclusively on young illiterates would be inequitable. Such a strategy might be most efficient strictly with respect to the aggregate effects of illiteracy on the national economy, but, after all, 'literacy has a role to play not only in the production, but also in the distribution of goods' (Bhola 1984, 251).

The present study shows that the customary cross-sectional ALR is not a good indicator of progress in supporting illiterates with equity in mind. This methodological critique is quite different from, and complementary to, the existing critiques of different processes of literacy monitoring and measurement (such as presented by Wagner (2008)). Arguably, changes in ALR do not measure changes in adult literacy, even if we take the individual observations at face value 
as valid measures of 'literacy'. Certainly, such changes do not measure the success of adult literacy programming. As a corollary, the ALR is not suitable for setting targets for the latter either. Because it is only contingently related to the success or failure of such programmes, the same quantitative target can place vastly divergent demands on different countries. It has been argued that the EFA goals were unfair on some countries in relation to others (Clemens et al. 2007; Easterly 2009), because they were going to be judged to have 'failed' even if expanding primary participation at a historically unprecedented pace. Similarly, halving adult illiteracy between 2000 and 2015 would in some countries have followed almost 'automatically' from achieving universal primary education, but would have required unprecedented success in adult education in others. In operationalising the literacy targets in the new Sustainable Development Goals (SDG) framework, the lessons learned from this study can provide useful guidance for measuring true progress towards SDG 4 and consequently implementing effective literacy programmes in the future. 
Appendix 
Table 1: Literacy rate (\%) for ages 20+ in the respective reporting year ('period') or cohorts aged 20-34 the initial year ('cohort'), their average annual percentage point changes $(\Delta)$, as well as the differences between the latter. Bootstrapped $95 \%$ confidence intervals in brackets. Data: DHS.

\begin{tabular}{|c|c|c|c|c|c|c|c|c|c|c|c|c|c|c|c|c|}
\hline \multirow[b]{3}{*}{ country } & \multirow[b]{3}{*}{ year } & \multicolumn{10}{|c|}{ female } & \multirow{2}{*}{\multicolumn{5}{|c|}{$\begin{array}{c}\text { male } \\
\text { full literacy }\end{array}$}} \\
\hline & & \multicolumn{5}{|c|}{ full literacy } & \multicolumn{5}{|c|}{ partial literacy } & & & & & \\
\hline & & $\begin{array}{l}\text { period } \\
(1)\end{array}$ & $\begin{array}{l}\text { cohort } \\
(2)\end{array}$ & $\begin{array}{l}\Delta(1) \\
(3)\end{array}$ & $\begin{array}{l}\Delta(2) \\
(4)\end{array}$ & $\begin{array}{l}(4)-(3) \\
(5)\end{array}$ & $\begin{array}{l}\text { period } \\
(6)\end{array}$ & $\begin{array}{l}\text { cohort } \\
(7)\end{array}$ & $\begin{array}{l}\Delta(6) \\
(8)\end{array}$ & $\begin{array}{l}\Delta(7) \\
(9)\end{array}$ & $\begin{array}{l}(9)-(8) \\
(10)\end{array}$ & $\begin{array}{l}\text { period } \\
(11)\end{array}$ & $\begin{array}{l}\text { cohort } \\
(12)\end{array}$ & $\begin{array}{l}\Delta(\mathbf{1 1}) \\
(13)\end{array}$ & $\begin{array}{l}\Delta(\mathbf{1 2}) \\
(14)\end{array}$ & $\begin{array}{l}(\mathbf{1 4})-(\mathbf{1 3}) \\
(15)\end{array}$ \\
\hline \multirow[t]{2}{*}{ Bangladesh } & 2007 & $\begin{array}{l}44.0 \\
{[42.9,45.1]}\end{array}$ & $\begin{array}{l}53.1 \\
{[51.6,54.6]}\end{array}$ & - & - & - & $\begin{array}{l}51.0 \\
{[49.8,52.1]}\end{array}$ & $\begin{array}{l}60.4 \\
{[58.9,61.8]}\end{array}$ & - & - & - & $\begin{array}{l}49.7 \\
{[47.9,51.5]}\end{array}$ & $\begin{array}{l}53.9 \\
{[50.6,57.0]}\end{array}$ & - & - & - \\
\hline & 2011 & $\begin{array}{l}50.0 \\
{[49.1,50.9]}\end{array}$ & $\begin{array}{l}52.4 \\
{[51.2,53.6]}\end{array}$ & $\begin{array}{l}1.5 \\
{[1.1,1.9]}\end{array}$ & $\begin{array}{l}-0.2 \\
{[-0.6,0.3]}\end{array}$ & $\begin{array}{l}-1.7 \\
{[-2.2,-1.1]}\end{array}$ & $\begin{array}{l}60.4 \\
{[59.6,61.2]}\end{array}$ & $\begin{array}{l}63.4 \\
{[62.3,64.7]}\end{array}$ & $\begin{array}{l}2.3 \\
{[2.0,2.7]}\end{array}$ & $\begin{array}{l}0.8 \\
{[0.3,1.3]}\end{array}$ & $\begin{array}{l}-1.6 \\
{[-2.2,-1.0]}\end{array}$ & $\begin{array}{l}47.9 \\
{[46.2,49.7]}\end{array}$ & $\begin{array}{l}51.3 \\
{[48.8,54.0]}\end{array}$ & $\begin{array}{l}-0.5 \\
{[-1.1,0.2]}\end{array}$ & $\begin{array}{l}-0.7 \\
{[-1.7,0.4]}\end{array}$ & $\begin{array}{l}-0.2 \\
{[-1.3,1.0]}\end{array}$ \\
\hline \multirow[t]{3}{*}{ Benin } & 2001 & $\begin{array}{l}16.6 \\
{[15.5,17.6]}\end{array}$ & $\begin{array}{l}17.8 \\
{[16.5,19.2]}\end{array}$ & - & - & - & $\begin{array}{l}22.0 \\
{[20.8,23.1]}\end{array}$ & $\begin{array}{l}24.3 \\
{[22.8,25.9]}\end{array}$ & - & - & - & $\begin{array}{l}36.2 \\
{[34.1,38.4]}\end{array}$ & $\begin{array}{l}39.7 \\
{[36.8,42.4]}\end{array}$ & - & - & - \\
\hline & 2006 & $\begin{array}{l}17.5 \\
{[16.8,18.1]}\end{array}$ & $\begin{array}{l}15.8 \\
{[15.1,16.7]}\end{array}$ & $\begin{array}{l}0.2 \\
{[-0.1,0.4]}\end{array}$ & $\begin{array}{l}-0.4 \\
{[-0.7,-0.1]}\end{array}$ & $\begin{array}{l}-0.6 \\
{[-1.0,-0.2]}\end{array}$ & $\begin{array}{l}23.9 \\
{[23.1,24.6]}\end{array}$ & $\begin{array}{l}22.8 \\
{[21.8,23.7]}\end{array}$ & $\begin{array}{l}0.4 \\
{[0.1,0.7]}\end{array}$ & $\begin{array}{l}-0.3 \\
{[-0.7,0.1]}\end{array}$ & $\begin{array}{l}-0.7 \\
{[-1.1,-0.2]}\end{array}$ & $\begin{array}{l}38.6 \\
{[37.0,40.1]}\end{array}$ & $\begin{array}{l}37.5 \\
{[35.4,39.7]}\end{array}$ & $\begin{array}{l}0.5 \\
{[-0.1,1.0]}\end{array}$ & $\begin{array}{l}-0.4 \\
{[-1.2,0.3]}\end{array}$ & $\begin{array}{l}-0.9 \\
{[-1.8,0.0]}\end{array}$ \\
\hline & 2011 & $\begin{array}{l}21.4 \\
{[20.6,22.2]}\end{array}$ & $\begin{array}{l}15.6 \\
{[14.6,16.6]}\end{array}$ & $\begin{array}{l}0.8 \\
{[0.6,1.0]}\end{array}$ & $\begin{array}{l}-0.1 \\
{[-0.3,0.2]}\end{array}$ & $\begin{array}{l}-0.8 \\
{[-1.2,-0.5]}\end{array}$ & $\begin{array}{l}28.7 \\
{[27.8,29.6]}\end{array}$ & $\begin{array}{l}23.0 \\
{[21.9,24.2]}\end{array}$ & $\begin{array}{l}1.0 \\
{[0.8,1.2]}\end{array}$ & $\begin{array}{l}0.0 \\
{[-0.2,0.3]}\end{array}$ & $\begin{array}{l}-0.9 \\
{[-1.3,-0.6]}\end{array}$ & $\begin{array}{l}42.5 \\
{[40.9,44.1]}\end{array}$ & $\begin{array}{l}38.9 \\
{[36.3,41.4]}\end{array}$ & $\begin{array}{l}0.8 \\
{[0.3,1.2]}\end{array}$ & $\begin{array}{l}0.3 \\
{[-0.4,0.9]}\end{array}$ & $\begin{array}{l}-0.5 \\
{[-1.2,0.3]}\end{array}$ \\
\hline \multirow[t]{2}{*}{ BurkinaFaso } & 2003 & $\begin{array}{l}9.8 \\
{[9.1,10.6]}\end{array}$ & $\begin{array}{l}12.7 \\
{[11.6,13.7]}\end{array}$ & - & - & - & $\begin{array}{l}13.1 \\
{[12.2,13.9]}\end{array}$ & $\begin{array}{l}16.5 \\
{[15.3,17.7]}\end{array}$ & - & - & - & $\begin{array}{l}22.1 \\
{[20.0,24.1]}\end{array}$ & $\begin{array}{l}28.3 \\
{[25.4,31.4]}\end{array}$ & - & - & - \\
\hline & 2010 & $\begin{array}{l}14.0 \\
{[13.3,14.7]}\end{array}$ & $\begin{array}{l}11.8 \\
{[10.9,12.6]}\end{array}$ & $\begin{array}{l}0.6 \\
{[0.4,0.7]}\end{array}$ & $\begin{array}{l}-0.1 \\
{[-0.3,0.1]}\end{array}$ & $\begin{array}{l}-0.7 \\
{[-1.0,-0.5]}\end{array}$ & $\begin{array}{l}19.0 \\
{[18.2,19.7]}\end{array}$ & $\begin{array}{l}16.3 \\
{[15.4,17.3]}\end{array}$ & $\begin{array}{l}0.8 \\
{[0.7,1.0]}\end{array}$ & $\begin{array}{l}0.0 \\
{[-0.3,0.2]}\end{array}$ & $\begin{array}{l}-0.9 \\
{[-1.1,-0.6]}\end{array}$ & $\begin{array}{l}26.0 \\
{[24.7,27.2]}\end{array}$ & $\begin{array}{l}27.0 \\
{[24.9,29.0]}\end{array}$ & $\begin{array}{l}0.6 \\
{[0.2,0.9]}\end{array}$ & $\begin{array}{l}-0.2 \\
{[-0.7,0.3]}\end{array}$ & $\begin{array}{l}-0.7 \\
{[-1.4,-0.1]}\end{array}$ \\
\hline \multirow[t]{2}{*}{ Cambodia } & 2005 & $\begin{array}{l}50.0 \\
{[48.9,51.1]}\end{array}$ & $\begin{array}{l}54.9 \\
{[53.5,56.3]}\end{array}$ & - & - & - & $\begin{array}{l}65.6 \\
{[64.6,66.5]}\end{array}$ & $\begin{array}{l}68.0 \\
{[66.7,69.3]}\end{array}$ & - & - & - & & & & & \\
\hline & 2010 & $\begin{array}{l}48.2 \\
{[47.2,49.2]}\end{array}$ & $\begin{array}{l}48.0 \\
{[46.5,49.4]}\end{array}$ & $\begin{array}{l}-0.4 \\
{[-0.6,-0.1]}\end{array}$ & $\begin{array}{l}-1.4 \\
{[-1.8,-1.0]}\end{array}$ & $\begin{array}{l}-1.0 \\
{[-1.5,-0.6]}\end{array}$ & $\begin{array}{l}69.7 \\
{[68.8,70.7]}\end{array}$ & $\begin{array}{l}69.1 \\
{[67.9,70.4]}\end{array}$ & $\begin{array}{l}0.8 \\
{[0.6,1.1]}\end{array}$ & $\begin{array}{l}0.2 \\
{[-0.1,0.6]}\end{array}$ & $\begin{array}{l}-0.6 \\
{[-1.1,-0.2]}\end{array}$ & & & & & \\
\hline \multirow[t]{2}{*}{ Cameroon } & 2004 & $\begin{array}{l}52.7 \\
{[51.5,53.9]}\end{array}$ & $\begin{array}{l}56.4 \\
{[55.0,57.8]}\end{array}$ & - & - & - & $\begin{array}{l}62.3 \\
{[61.2,63.5]}\end{array}$ & $\begin{array}{l}65.9 \\
{[64.5,67.3]}\end{array}$ & - & - & - & $\begin{array}{l}68.2 \\
{[66.7,69.8]}\end{array}$ & $\begin{array}{l}71.5 \\
{[69.4,73.3]}\end{array}$ & - & - & - \\
\hline & 2011 & $\begin{array}{l}56.5 \\
{[55.5,57.6]}\end{array}$ & $\begin{array}{l}54.4 \\
{[53.0,55.9]}\end{array}$ & $\begin{array}{l}0.5 \\
{[0.3,0.8]}\end{array}$ & $\begin{array}{l}-0.3 \\
{[-0.6,0.0]}\end{array}$ & $\begin{array}{l}-0.8 \\
{[-1.2,-0.5]}\end{array}$ & $\begin{array}{l}67.4 \\
{[66.4,68.4]}\end{array}$ & $\begin{array}{l}66.0 \\
{[64.6,67.4]}\end{array}$ & $\begin{array}{l}0.7 \\
{[0.5,0.9]}\end{array}$ & $\begin{array}{l}0.0 \\
{[-0.3,0.3]}\end{array}$ & $\begin{array}{l}-0.7 \\
{[-1.1,-0.3]}\end{array}$ & $\begin{array}{l}72.9 \\
{[71.5,74.2]}\end{array}$ & $\begin{array}{l}72.9 \\
{[70.9,75.0]}\end{array}$ & $\begin{array}{l}0.7 \\
{[0.4,1.0]}\end{array}$ & $\begin{array}{l}0.2 \\
{[-0.2,0.6]}\end{array}$ & $\begin{array}{l}-0.5 \\
{[-0.9,0.0]}\end{array}$ \\
\hline \multirow[t]{2}{*}{ Congo } & 2005 & $\begin{array}{l}68.3 \\
{[66.8,69.8]}\end{array}$ & $\begin{array}{l}69.1 \\
{[67.3,71.0]}\end{array}$ & - & - & - & $\begin{array}{l}78.7 \\
{[77.2,79.9]}\end{array}$ & $\begin{array}{l}80.1 \\
{[78.4,81.8]}\end{array}$ & - & - & - & $\begin{array}{l}84.3 \\
{[82.6,86.1]}\end{array}$ & $\begin{array}{l}82.6 \\
{[80.2,84.9]}\end{array}$ & - & - & - \\
\hline & 2011 & $\begin{array}{l}73.7 \\
{[72.4,74.9]}\end{array}$ & $\begin{array}{l}73.7 \\
{[72.1,75.3]}\end{array}$ & $\begin{array}{l}0.9 \\
{[0.6,1.3]}\end{array}$ & $\begin{array}{l}0.8 \\
{[0.4,1.2]}\end{array}$ & $\begin{array}{l}-0.1 \\
{[-0.7,0.4]}\end{array}$ & $\begin{array}{l}82.0 \\
{[80.9,83.1]}\end{array}$ & $\begin{array}{l}82.5 \\
{[81.0,83.9]}\end{array}$ & $\begin{array}{l}0.6 \\
{[0.3,0.8]}\end{array}$ & $\begin{array}{l}0.4 \\
{[0.0,0.7]}\end{array}$ & $\begin{array}{l}-0.2 \\
{[-0.6,0.3]}\end{array}$ & $\begin{array}{l}86.0 \\
{[84.5,87.4]}\end{array}$ & $\begin{array}{l}84.4 \\
{[82.2,86.5]}\end{array}$ & $\begin{array}{l}0.3 \\
{[-0.1,0.7]}\end{array}$ & $\begin{array}{l}0.3 \\
{[-0.2,0.8]}\end{array}$ & $\begin{array}{l}0.0 \\
{[-0.6,0.7]}\end{array}$ \\
\hline
\end{tabular}


Table 1: continued

\begin{tabular}{|c|c|c|c|c|c|c|c|c|c|c|c|c|c|c|c|c|}
\hline \multirow[b]{3}{*}{ country } & \multirow[b]{3}{*}{ year } & \multicolumn{10}{|c|}{ female } & \multirow{2}{*}{\multicolumn{5}{|c|}{$\begin{array}{c}\text { male } \\
\text { full literacy }\end{array}$}} \\
\hline & & \multicolumn{5}{|c|}{ full literacy } & \multicolumn{5}{|c|}{ partial literacy } & & & & & \\
\hline & & $\begin{array}{l}\text { period } \\
\text { (1) }\end{array}$ & $\begin{array}{l}\text { cohort } \\
(2)\end{array}$ & $\begin{array}{l}\Delta(1) \\
(3)\end{array}$ & $\begin{array}{l}\Delta(2) \\
(4)\end{array}$ & $\begin{array}{l}(4)-(3) \\
(5)\end{array}$ & $\begin{array}{l}\text { period } \\
(6)\end{array}$ & $\begin{array}{l}\text { cohort } \\
(7)\end{array}$ & $\begin{array}{l}\Delta(6) \\
(8)\end{array}$ & $\begin{array}{l}\Delta(7) \\
(9)\end{array}$ & $\begin{array}{l}(\mathbf{9})-(\mathbf{8}) \\
(10)\end{array}$ & $\begin{array}{l}\text { period } \\
(11)\end{array}$ & $\begin{array}{l}\text { cohort } \\
(12)\end{array}$ & $\begin{array}{l}\Delta(11) \\
(13)\end{array}$ & $\begin{array}{l}\Delta(\mathbf{1 2}) \\
(14)\end{array}$ & $\begin{array}{l}(\mathbf{1 4})-(\mathbf{1 3}) \\
(15)\end{array}$ \\
\hline \multirow[t]{2}{*}{ DominicanRepublic } & 2002 & $\begin{array}{l}83.5 \\
{[82.8,84.2]}\end{array}$ & $\begin{array}{l}87.8 \\
{[87.1,88.6]}\end{array}$ & - & - & - & $\begin{array}{l}89.2 \\
{[88.6,89.7]}\end{array}$ & $\begin{array}{l}92.5 \\
{[91.9,93.1]}\end{array}$ & - & - & - & $\begin{array}{l}80.1 \\
{[78.0,82.1]}\end{array}$ & $\begin{array}{l}83.1 \\
{[80.2,85.8]}\end{array}$ & - & - & - \\
\hline & 2007 & $\begin{array}{l}85.5 \\
{[84.9,86.1]}\end{array}$ & $\begin{array}{l}86.7 \\
{[85.7,87.5]}\end{array}$ & $\begin{array}{l}0.4 \\
{[0.2,0.6]}\end{array}$ & $\begin{array}{l}-0.2 \\
{[-0.5,0.0]}\end{array}$ & $\begin{array}{l}-0.6 \\
{[-0.9,-0.3]}\end{array}$ & $\begin{array}{l}91.8 \\
{[91.3,92.3]}\end{array}$ & $\begin{array}{l}92.6 \\
{[91.9,93.2]}\end{array}$ & $\begin{array}{l}0.5 \\
{[0.4,0.7]}\end{array}$ & $\begin{array}{l}0.0 \\
{[-0.2,0.2]}\end{array}$ & $\begin{array}{l}-0.5 \\
{[-0.7,-0.3]}\end{array}$ & $\begin{array}{l}81.0 \\
{[80.3,81.7]}\end{array}$ & $\begin{array}{l}83.6 \\
{[82.7,84.6]}\end{array}$ & $\begin{array}{l}0.2 \\
{[-0.3,0.7]}\end{array}$ & $\begin{array}{l}0.1 \\
{[-0.4,0.7]}\end{array}$ & $\begin{array}{l}-0.1 \\
{[-0.8,0.7]}\end{array}$ \\
\hline \multirow[t]{3}{*}{ Ethiopia } & 2000 & $\begin{array}{l}15.8 \\
{[14.9,16.7]}\end{array}$ & $\begin{array}{l}20.8 \\
{[19.5,22.2]}\end{array}$ & - & - & - & $\begin{array}{l}21.9 \\
{[20.8,22.9]}\end{array}$ & $\begin{array}{l}27.8 \\
{[26.5,29.3]}\end{array}$ & - & - & - & $\begin{array}{l}39.5 \\
{[36.6,42.4]}\end{array}$ & $\begin{array}{l}47.7 \\
{[43.6,51.9]}\end{array}$ & - & - & - \\
\hline & 2005 & $\begin{array}{l}16.5 \\
{[15.6,17.4]}\end{array}$ & $\begin{array}{l}16.5 \\
{[15.3,17.8]}\end{array}$ & $\begin{array}{l}0.1 \\
{[-0.1,0.4]}\end{array}$ & $\begin{array}{l}-0.9 \\
{[-1.2,-0.5]}\end{array}$ & $\begin{array}{l}-1.0 \\
{[-1.4,-0.6]}\end{array}$ & $\begin{array}{l}23.4 \\
{[22.3,24.4]}\end{array}$ & $\begin{array}{l}24.2 \\
{[22.7,25.6]}\end{array}$ & $\begin{array}{l}0.3 \\
{[0.0,0.6]}\end{array}$ & $\begin{array}{l}-0.7 \\
{[-1.1,-0.3]}\end{array}$ & $\begin{array}{l}-1.0 \\
{[-1.5,-0.5]}\end{array}$ & $\begin{array}{l}41.8 \\
{[40.0,43.5]}\end{array}$ & $\begin{array}{l}44.4 \\
{[41.5,47.0]}\end{array}$ & $\begin{array}{l}0.5 \\
{[-0.3,1.2]}\end{array}$ & $\begin{array}{l}-0.7 \\
{[-1.7,0.3]}\end{array}$ & $\begin{array}{l}-1.1 \\
{[-2.3,0.1]}\end{array}$ \\
\hline & 2011 & $\begin{array}{l}21.1 \\
{[20.1,22.2]}\end{array}$ & $\begin{array}{l}15.4 \\
{[14.0,17.0]}\end{array}$ & $\begin{array}{l}0.8 \\
{[0.5,1.0]}\end{array}$ & $\begin{array}{l}-0.2 \\
{[-0.5,0.1]}\end{array}$ & $\begin{array}{l}-1.0 \\
{[-1.3,-0.6]}\end{array}$ & $\begin{array}{l}30.7 \\
{[29.5,31.9]}\end{array}$ & $\begin{array}{l}25.5 \\
{[23.9,27.2]}\end{array}$ & $\begin{array}{l}1.2 \\
{[1.0,1.5]}\end{array}$ & $\begin{array}{l}0.2 \\
{[-0.2,0.6]}\end{array}$ & $\begin{array}{l}-1.0 \\
{[-1.4,-0.5]}\end{array}$ & $\begin{array}{l}45.2 \\
{[43.9,46.6]}\end{array}$ & $\begin{array}{l}41.7 \\
{[39.5,43.9]}\end{array}$ & $\begin{array}{l}0.6 \\
{[0.2,1.0]}\end{array}$ & $\begin{array}{l}-0.4 \\
{[-1.1,0.2]}\end{array}$ & $\begin{array}{l}-1.0 \\
{[-1.7,-0.3]}\end{array}$ \\
\hline \multirow[t]{2}{*}{ Ghana } & 2003 & $\begin{array}{l}27.8 \\
{[26.4,29.2]}\end{array}$ & $\begin{array}{l}28.6 \\
{[26.8,30.4]}\end{array}$ & - & - & - & $\begin{array}{l}36.8 \\
{[35.2,38.4]}\end{array}$ & $\begin{array}{l}38.2 \\
{[36.4,40.4]}\end{array}$ & - & - & - & $\begin{array}{l}54.6 \\
{[52.8,56.3]}\end{array}$ & $\begin{array}{l}55.2 \\
{[52.8,57.5]}\end{array}$ & - & - & - \\
\hline & 2008 & $\begin{array}{l}31.8 \\
{[30.1,33.3]}\end{array}$ & $\begin{array}{l}28.3 \\
{[26.2,30.7]}\end{array}$ & $\begin{array}{l}0.8 \\
{[0.3,1.2]}\end{array}$ & $\begin{array}{l}-0.1 \\
{[-0.6,0.5]}\end{array}$ & $\begin{array}{l}-0.9 \\
{[-1.5,-0.1]}\end{array}$ & $\begin{array}{l}44.0 \\
{[42.3,45.6]}\end{array}$ & $\begin{array}{l}40.9 \\
{[38.4,43.2]}\end{array}$ & $\begin{array}{l}1.4 \\
{[1.0,1.9]}\end{array}$ & $\begin{array}{l}0.5 \\
{[-0.1,1.1]}\end{array}$ & $\begin{array}{l}-0.9 \\
{[-1.7,-0.1]}\end{array}$ & $\begin{array}{l}52.4 \\
{[50.5,54.2]}\end{array}$ & $\begin{array}{l}49.6 \\
{[47.0,52.3]}\end{array}$ & $\begin{array}{l}-0.4 \\
{[-0.9,0.0]}\end{array}$ & $\begin{array}{l}-1.1 \\
{[-1.8,-0.4]}\end{array}$ & $\begin{array}{l}-0.7 \\
{[-1.5,0.2]}\end{array}$ \\
\hline \multirow[t]{2}{*}{ Guinea } & 2005 & $\begin{array}{l}8.7 \\
{[7.9,9.5]}\end{array}$ & $\begin{array}{l}10.1 \\
{[9.0,11.2]}\end{array}$ & - & - & - & $\begin{array}{l}11.0 \\
{[10.1,11.8]}\end{array}$ & $\begin{array}{l}12.8 \\
{[11.6,14.1]}\end{array}$ & - & - & - & $\begin{array}{l}32.5 \\
{[30.5,34.6]}\end{array}$ & $\begin{array}{l}40.7 \\
{[37.4,43.8]}\end{array}$ & - & - & - \\
\hline & 2012 & $\begin{array}{l}16.2 \\
{[15.2,17.2]}\end{array}$ & $\begin{array}{l}10.8 \\
{[9.6,12.0]}\end{array}$ & $\begin{array}{l}1.1 \\
{[0.9,1.3]}\end{array}$ & $\begin{array}{l}0.1 \\
{[-0.1,0.3]}\end{array}$ & $\begin{array}{l}-1.0 \\
{[-1.3,-0.7]}\end{array}$ & $\begin{array}{l}18.3 \\
{[17.3,19.4]}\end{array}$ & $\begin{array}{l}12.5 \\
{[11.3,13.8]}\end{array}$ & $\begin{array}{l}1.1 \\
{[0.9,1.2]}\end{array}$ & $\begin{array}{l}0.0 \\
{[-0.3,0.2]}\end{array}$ & $\begin{array}{l}-1.1 \\
{[-1.4,-0.8]}\end{array}$ & $\begin{array}{l}40.1 \\
{[38.0,42.1]}\end{array}$ & $\begin{array}{l}34.9 \\
{[31.6,38.2]}\end{array}$ & $\begin{array}{l}1.1 \\
{[0.6,1.5]}\end{array}$ & $\begin{array}{l}-0.8 \\
{[-1.5,-0.2]}\end{array}$ & $\begin{array}{l}-1.9 \\
{[-2.7,-1.1]}\end{array}$ \\
\hline \multirow[t]{2}{*}{ Honduras } & 2005 & $\begin{array}{l}86.5 \\
{[85.9,87.0]}\end{array}$ & $\begin{array}{l}89.5 \\
{[88.8,90.2]}\end{array}$ & - & - & - & $\begin{array}{l}88.2 \\
{[87.6,88.8]}\end{array}$ & $\begin{array}{l}90.9 \\
{[90.3,91.5]}\end{array}$ & - & - & - & & & & & \\
\hline & 2011 & $\begin{array}{l}90.8 \\
{[90.3,91.2]}\end{array}$ & $\begin{array}{l}91.0 \\
{[90.3,91.6]}\end{array}$ & $\begin{array}{l}0.7 \\
{[0.6,0.8]}\end{array}$ & $\begin{array}{l}0.2 \\
{[0.1,0.4]}\end{array}$ & $\begin{array}{l}-0.5 \\
{[-0.7,-0.3]}\end{array}$ & $\begin{array}{l}91.7 \\
{[91.3,92.1]}\end{array}$ & $\begin{array}{l}91.9 \\
{[91.2,92.5]}\end{array}$ & $\begin{array}{l}0.6 \\
{[0.5,0.7]}\end{array}$ & $\begin{array}{l}0.2 \\
{[0.0,0.3]}\end{array}$ & $\begin{array}{l}-0.4 \\
{[-0.6,-0.2]}\end{array}$ & & & & & \\
\hline \multirow[t]{3}{*}{ Indonesia } & 2002 & $\begin{array}{l}78.0 \\
{[77.2,78.8]}\end{array}$ & $\begin{array}{l}89.2 \\
{[88.3,90.0]}\end{array}$ & - & - & - & $\begin{array}{l}86.6 \\
{[85.9,87.2]}\end{array}$ & $\begin{array}{l}94.4 \\
{[93.8,95.0]}\end{array}$ & - & - & - & $\begin{array}{l}86.5 \\
{[85.3,87.7]}\end{array}$ & $\begin{array}{l}93.9 \\
{[92.5,95.0]}\end{array}$ & - & - & - \\
\hline & 2007 & $\begin{array}{l}79.7 \\
{[79.0,80.5]}\end{array}$ & $\begin{array}{l}86.8 \\
{[86.1,87.5]}\end{array}$ & $\begin{array}{l}0.4 \\
{[0.1,0.6]}\end{array}$ & $\begin{array}{l}-0.5 \\
{[-0.7,-0.2]}\end{array}$ & $\begin{array}{l}-0.8 \\
{[-1.2,-0.5]}\end{array}$ & $\begin{array}{l}87.6 \\
{[87.0,88.2]}\end{array}$ & $\begin{array}{l}92.9 \\
{[92.3,93.4]}\end{array}$ & $\begin{array}{l}0.2 \\
{[0.0,0.4]}\end{array}$ & $\begin{array}{l}-0.3 \\
{[-0.5,-0.1]}\end{array}$ & $\begin{array}{l}-0.5 \\
{[-0.8,-0.3]}\end{array}$ & $\begin{array}{l}84.9 \\
{[83.8,86.1]}\end{array}$ & $\begin{array}{l}91.7 \\
{[90.4,92.9]}\end{array}$ & $\begin{array}{l}-0.3 \\
{[-0.7,0.0]}\end{array}$ & $\begin{array}{l}-0.4 \\
{[-0.8,-0.1]}\end{array}$ & $\begin{array}{l}-0.1 \\
{[-0.6,0.4]}\end{array}$ \\
\hline & 2012 & $\begin{array}{l}87.2 \\
{[86.7,87.7]}\end{array}$ & $\begin{array}{l}87.6 \\
{[86.9,88.2]}\end{array}$ & $\begin{array}{l}1.5 \\
{[1.3,1.7]}\end{array}$ & $\begin{array}{l}0.2 \\
{[-0.1,0.4]}\end{array}$ & $\begin{array}{l}-1.3 \\
{[-1.6,-1.1]}\end{array}$ & $\begin{array}{l}92.5 \\
{[92.2,92.9]}\end{array}$ & $\begin{array}{l}93.3 \\
{[92.8,93.7]}\end{array}$ & $\begin{array}{l}1.0 \\
{[0.9,1.1]}\end{array}$ & $\begin{array}{l}0.1 \\
{[-0.1,0.2]}\end{array}$ & $\begin{array}{l}-0.9 \\
{[-1.1,-0.7]}\end{array}$ & $\begin{array}{l}89.3 \\
{[88.3,90.2]}\end{array}$ & $\begin{array}{l}93.2 \\
{[92.2,94.2]}\end{array}$ & $\begin{array}{l}0.9 \\
{[0.6,1.2]}\end{array}$ & $\begin{array}{l}0.3 \\
{[0.0,0.6]}\end{array}$ & $\begin{array}{l}-0.6 \\
{[-1.0,-0.1]}\end{array}$ \\
\hline
\end{tabular}


Table 1: continued

\begin{tabular}{|c|c|c|c|c|c|c|c|c|c|c|c|c|c|c|c|c|}
\hline \multirow[b]{3}{*}{ country } & \multirow[b]{3}{*}{ year } & \multicolumn{10}{|c|}{ female } & \multirow{2}{*}{\multicolumn{5}{|c|}{$\begin{array}{c}\text { male } \\
\text { full literacy }\end{array}$}} \\
\hline & & \multicolumn{5}{|c|}{ full literacy } & \multicolumn{5}{|c|}{ partial literacy } & & & & & \\
\hline & & $\begin{array}{l}\text { period } \\
\text { (1) }\end{array}$ & $\begin{array}{l}\text { cohort } \\
(2)\end{array}$ & $\begin{array}{l}\Delta(1) \\
(3)\end{array}$ & $\begin{array}{l}\Delta(2) \\
(4)\end{array}$ & $\begin{array}{l}(4)-(3) \\
(5)\end{array}$ & $\begin{array}{l}\text { period } \\
(6)\end{array}$ & $\begin{array}{l}\text { cohort } \\
(7)\end{array}$ & $\begin{array}{l}\Delta(6) \\
(8)\end{array}$ & $\begin{array}{l}\Delta(7) \\
(9)\end{array}$ & $\begin{array}{l}(\mathbf{9})-(\mathbf{8}) \\
(10)\end{array}$ & $\begin{array}{l}\text { period } \\
(11)\end{array}$ & $\begin{array}{l}\text { cohort } \\
(12)\end{array}$ & $\begin{array}{l}\Delta(11) \\
(13)\end{array}$ & $\begin{array}{l}\Delta(\mathbf{1 2}) \\
(14)\end{array}$ & $\begin{array}{l}(\mathbf{1 4})-(\mathbf{1 3}) \\
(15)\end{array}$ \\
\hline \multirow[t]{2}{*}{ Kenya } & 2003 & $\begin{array}{l}69.2 \\
{[67.9,70.5]}\end{array}$ & $\begin{array}{l}77.1 \\
{[75.8,78.6]}\end{array}$ & - & - & - & $\begin{array}{l}76.6 \\
{[75.5,77.7]}\end{array}$ & $\begin{array}{l}83.7 \\
{[82.5,84.9]}\end{array}$ & - & - & - & $\begin{array}{l}82.1 \\
{[80.6,83.7]}\end{array}$ & $\begin{array}{l}85.7 \\
{[83.9,87.6]}\end{array}$ & - & - & - \\
\hline & 2008 & $\begin{array}{l}71.3 \\
{[69.6,72.8]}\end{array}$ & $\begin{array}{l}73.5 \\
{[71.2,75.5]}\end{array}$ & $\begin{array}{l}0.4 \\
{[0.0,0.8]}\end{array}$ & $\begin{array}{l}-0.7 \\
{[-1.2,-0.2]}\end{array}$ & $\begin{array}{l}-1.1 \\
{[-1.8,-0.4]}\end{array}$ & $\begin{array}{l}83.8 \\
{[82.7,85.0]}\end{array}$ & $\begin{array}{l}86.1 \\
{[84.5,87.6]}\end{array}$ & $\begin{array}{l}1.4 \\
{[1.1,1.7]}\end{array}$ & $\begin{array}{l}0.5 \\
{[0.1,0.9]}\end{array}$ & $\begin{array}{l}-1.0 \\
{[-1.5,-0.5]}\end{array}$ & $\begin{array}{l}78.2 \\
{[76.0,80.4]}\end{array}$ & $\begin{array}{l}79.3 \\
{[76.0,82.2]}\end{array}$ & $\begin{array}{l}-0.8 \\
{[-1.3,-0.2]}\end{array}$ & $\begin{array}{l}-1.3 \\
{[-2.0,-0.5]}\end{array}$ & $\begin{array}{l}-0.5 \\
{[-1.4,0.4]}\end{array}$ \\
\hline \multirow[t]{2}{*}{ Lesotho } & 2004 & $\begin{array}{l}89.5 \\
{[88.6,90.4]}\end{array}$ & $\begin{array}{l}91.2 \\
{[90.1,92.3]}\end{array}$ & - & - & - & $\begin{array}{l}94.8 \\
{[94.2,95.5]}\end{array}$ & $\begin{array}{l}96.2 \\
{[95.4,96.8]}\end{array}$ & - & - & - & $\begin{array}{l}64.2 \\
{[61.9,66.4]}\end{array}$ & $\begin{array}{l}67.8 \\
{[64.8,70.6]}\end{array}$ & - & - & - \\
\hline & 2009 & $\begin{array}{l}88.2 \\
{[87.2,89.1]}\end{array}$ & $\begin{array}{l}88.9 \\
{[87.6,90.0]}\end{array}$ & $\begin{array}{l}-0.2 \\
{[-0.5,0.0]}\end{array}$ & $\begin{array}{l}-0.5 \\
{[-0.8,-0.1]}\end{array}$ & $\begin{array}{l}-0.2 \\
{[-0.6,0.2]}\end{array}$ & $\begin{array}{l}96.5 \\
{[96.0,97.0]}\end{array}$ & $\begin{array}{l}96.8 \\
{[96.1,97.5]}\end{array}$ & $\begin{array}{l}0.3 \\
{[0.2,0.5]}\end{array}$ & $\begin{array}{l}0.1 \\
{[-0.1,0.3]}\end{array}$ & $\begin{array}{l}-0.2 \\
{[-0.5,0.1]}\end{array}$ & $\begin{array}{l}64.9 \\
{[62.7,66.9]}\end{array}$ & $\begin{array}{l}63.6 \\
{[60.4,66.8]}\end{array}$ & $\begin{array}{l}0.1 \\
{[-0.5,0.7]}\end{array}$ & $\begin{array}{l}-0.8 \\
{[-1.7,0.0]}\end{array}$ & $\begin{array}{l}-1.0 \\
{[-2.0,0.1]}\end{array}$ \\
\hline \multirow[t]{2}{*}{ Madagascar } & 2003 & $\begin{array}{l}61.1 \\
{[59.2,62.7]}\end{array}$ & $\begin{array}{l}60.9 \\
{[58.7,63.2]}\end{array}$ & - & - & - & $\begin{array}{l}71.2 \\
{[69.6,72.7]}\end{array}$ & $\begin{array}{l}71.6 \\
{[69.5,73.7]}\end{array}$ & - & - & - & $\begin{array}{l}62.4 \\
{[59.5,65.2]}\end{array}$ & $\begin{array}{l}58.9 \\
{[54.8,63.2]}\end{array}$ & - & - & - \\
\hline & 2008 & $\begin{array}{l}60.5 \\
{[59.5,61.5]}\end{array}$ & $\begin{array}{l}60.6 \\
{[59.2,62.1]}\end{array}$ & $\begin{array}{l}-0.1 \\
{[-0.5,0.3]}\end{array}$ & $\begin{array}{l}0.0 \\
{[-0.6,0.5]}\end{array}$ & $\begin{array}{l}0.1 \\
{[-0.6,0.7]}\end{array}$ & $\begin{array}{l}73.2 \\
{[72.3,74.1]}\end{array}$ & $\begin{array}{l}73.2 \\
{[71.9,74.4]}\end{array}$ & $\begin{array}{l}0.4 \\
{[0.0,0.8]}\end{array}$ & $\begin{array}{l}0.3 \\
{[-0.2,0.8]}\end{array}$ & $\begin{array}{l}-0.1 \\
{[-0.7,0.5]}\end{array}$ & $\begin{array}{l}66.7 \\
{[65.4,68.0]}\end{array}$ & $\begin{array}{l}64.3 \\
{[62.4,66.4]}\end{array}$ & $\begin{array}{l}0.9 \\
{[0.2,1.5]}\end{array}$ & $\begin{array}{l}1.1 \\
{[0.2,2.0]}\end{array}$ & $\begin{array}{l}0.2 \\
{[-0.7,1.3]}\end{array}$ \\
\hline \multirow[t]{3}{*}{ Malawi } & 2000 & $\begin{array}{l}43.5 \\
{[42.5,44.6]}\end{array}$ & $\begin{array}{l}49.1 \\
{[47.6,50.4]}\end{array}$ & - & - & - & $\begin{array}{l}51.2 \\
{[50.1,52.3]}\end{array}$ & $\begin{array}{l}57.0 \\
{[55.7,58.3]}\end{array}$ & - & - & - & $\begin{array}{l}71.9 \\
{[69.8,73.9]}\end{array}$ & $\begin{array}{l}74.8 \\
{[72.4,77.4]}\end{array}$ & - & - & - \\
\hline & 2004 & $\begin{array}{l}49.8 \\
{[48.6,51.0]}\end{array}$ & $\begin{array}{l}48.4 \\
{[46.8,50.0]}\end{array}$ & $\begin{array}{l}1.6 \\
{[1.2,2.0]}\end{array}$ & $\begin{array}{l}-0.2 \\
{[-0.7,0.4]}\end{array}$ & $\begin{array}{l}-1.7 \\
{[-2.4,-1.1]}\end{array}$ & $\begin{array}{l}58.5 \\
{[57.4,59.6]}\end{array}$ & $\begin{array}{l}57.5 \\
{[55.8,59.0]}\end{array}$ & $\begin{array}{l}1.8 \\
{[1.4,2.2]}\end{array}$ & $\begin{array}{l}0.1 \\
{[-0.5,0.6]}\end{array}$ & $\begin{array}{l}-1.7 \\
{[-2.4,-1.0]}\end{array}$ & $\begin{array}{l}74.5 \\
{[72.4,76.4]}\end{array}$ & $\begin{array}{l}74.6 \\
{[72.0,77.1]}\end{array}$ & $\begin{array}{l}0.6 \\
{[-0.1,1.3]}\end{array}$ & $\begin{array}{l}-0.1 \\
{[-1.0,0.8]}\end{array}$ & $\begin{array}{l}-0.7 \\
{[-1.9,0.5]}\end{array}$ \\
\hline & 2010 & $\begin{array}{l}56.0 \\
{[55.1,56.9]}\end{array}$ & $\begin{array}{l}48.7 \\
{[47.2,50.1]}\end{array}$ & $\begin{array}{l}1.0 \\
{[0.8,1.3]}\end{array}$ & $\begin{array}{l}0.0 \\
{[-0.3,0.4]}\end{array}$ & $\begin{array}{l}-1.0 \\
{[-1.4,-0.6]}\end{array}$ & $\begin{array}{l}64.2 \\
{[63.3,65.0]}\end{array}$ & $\begin{array}{l}57.1 \\
{[55.7,58.6]}\end{array}$ & $\begin{array}{l}0.9 \\
{[0.7,1.2]}\end{array}$ & $\begin{array}{l}-0.1 \\
{[-0.4,0.3]}\end{array}$ & $\begin{array}{l}-1.0 \\
{[-1.4,-0.6]}\end{array}$ & $\begin{array}{l}73.2 \\
{[71.7,74.6]}\end{array}$ & $\begin{array}{l}71.7 \\
{[69.2,74.2]}\end{array}$ & $\begin{array}{l}-0.2 \\
{[-0.6,0.2]}\end{array}$ & $\begin{array}{l}-0.5 \\
{[-1.0,0.1]}\end{array}$ & $\begin{array}{l}-0.3 \\
{[-1.0,0.5]}\end{array}$ \\
\hline \multirow[t]{2}{*}{ Mali } & 2001 & $\begin{array}{l}8.9 \\
{[8.2,9.6]}\end{array}$ & $\begin{array}{l}9.6 \\
{[8.8,10.5]}\end{array}$ & - & - & - & $\begin{array}{l}13.2 \\
{[12.4,14.0]}\end{array}$ & $\begin{array}{l}14.0 \\
{[13.0,15.0]}\end{array}$ & - & - & - & $\begin{array}{l}20.9 \\
{[19.1,22.8]}\end{array}$ & $\begin{array}{l}23.4 \\
{[20.7,26.2]}\end{array}$ & - & - & - \\
\hline & 2006 & $\begin{array}{l}8.8 \\
{[8.2,9.5]}\end{array}$ & $\begin{array}{l}6.8 \\
{[6.0,7.5]}\end{array}$ & $\begin{array}{l}0.0 \\
{[-0.2,0.2]}\end{array}$ & $\begin{array}{l}-0.6 \\
{[-0.8,-0.4]}\end{array}$ & $\begin{array}{l}-0.6 \\
{[-0.8,-0.3]}\end{array}$ & $\begin{array}{l}13.1 \\
{[12.4,13.9]}\end{array}$ & $\begin{array}{l}11.3 \\
{[10.4,12.3]}\end{array}$ & $\begin{array}{l}0.0 \\
{[-0.2,0.2]}\end{array}$ & $\begin{array}{l}-0.5 \\
{[-0.8,-0.2]}\end{array}$ & $\begin{array}{l}-0.5 \\
{[-0.9,-0.2]}\end{array}$ & $\begin{array}{l}22.1 \\
{[20.4,23.9]}\end{array}$ & $\begin{array}{l}19.5 \\
{[17.0,22.1]}\end{array}$ & $\begin{array}{l}0.2 \\
{[-0.3,0.7]}\end{array}$ & $\begin{array}{l}-0.8 \\
{[-1.6,0.0]}\end{array}$ & $\begin{array}{l}-1.0 \\
{[-1.9,-0.1]}\end{array}$ \\
\hline \multirow[t]{2}{*}{ Mozambique } & 2003 & $\begin{array}{l}26.9 \\
{[25.9,28.0]}\end{array}$ & $\begin{array}{l}30.7 \\
{[29.4,32.0]}\end{array}$ & - & - & - & $\begin{array}{l}33.1 \\
{[32.0,34.2]}\end{array}$ & $\begin{array}{l}36.6 \\
{[35.1,38.2]}\end{array}$ & - & - & - & $\begin{array}{l}55.3 \\
{[52.7,58.0]}\end{array}$ & $\begin{array}{l}60.0 \\
{[56.4,63.9]}\end{array}$ & - & - & - \\
\hline & 2011 & $\begin{array}{l}28.6 \\
{[27.7,29.6]}\end{array}$ & $\begin{array}{l}24.5 \\
{[23.3,25.8]}\end{array}$ & $\begin{array}{l}0.2 \\
{[0.0,0.4]}\end{array}$ & $\begin{array}{l}-0.8 \\
{[-1.0,-0.6]}\end{array}$ & $\begin{array}{l}-1.0 \\
{[-1.3,-0.7]}\end{array}$ & $\begin{array}{l}35.0 \\
{[34.0,36.1]}\end{array}$ & $\begin{array}{l}30.7 \\
{[29.4,32.1]}\end{array}$ & $\begin{array}{l}0.2 \\
{[0.1,0.4]}\end{array}$ & $\begin{array}{l}-0.7 \\
{[-1.0,-0.5]}\end{array}$ & $\begin{array}{l}-1.0 \\
{[-1.3,-0.7]}\end{array}$ & $\begin{array}{l}56.1 \\
{[54.1,58.3]}\end{array}$ & $\begin{array}{l}52.1 \\
{[48.6,55.2]}\end{array}$ & $\begin{array}{l}0.1 \\
{[-0.3,0.5]}\end{array}$ & $\begin{array}{l}-1.0 \\
{[-1.6,-0.4]}\end{array}$ & $\begin{array}{l}-1.1 \\
{[-1.8,-0.4]}\end{array}$ \\
\hline
\end{tabular}

(Continued on next page) 
Table 1: continued

\begin{tabular}{|c|c|c|c|c|c|c|c|c|c|c|c|c|c|c|c|c|}
\hline \multirow[b]{3}{*}{ country } & \multirow[b]{3}{*}{ year } & \multicolumn{10}{|c|}{ female } & \multirow{2}{*}{\multicolumn{5}{|c|}{$\begin{array}{c}\text { male } \\
\text { full literacy }\end{array}$}} \\
\hline & & \multicolumn{5}{|c|}{ full literacy } & \multicolumn{5}{|c|}{ partial literacy } & & & & & \\
\hline & & $\begin{array}{l}\text { period } \\
\text { (1) }\end{array}$ & $\begin{array}{l}\text { cohort } \\
(2)\end{array}$ & $\begin{array}{l}\Delta(1) \\
(3)\end{array}$ & $\begin{array}{l}\Delta(2) \\
(4)\end{array}$ & $\begin{array}{l}(4)-(3) \\
(5)\end{array}$ & $\begin{array}{l}\text { period } \\
(6)\end{array}$ & $\begin{array}{l}\text { cohort } \\
(7)\end{array}$ & $\begin{array}{l}\Delta(6) \\
(8)\end{array}$ & $\begin{array}{l}\Delta(7) \\
(9)\end{array}$ & $\begin{array}{l}(\mathbf{9})-(8) \\
(10)\end{array}$ & $\begin{array}{l}\text { period } \\
(11)\end{array}$ & $\begin{array}{l}\text { cohort } \\
(12)\end{array}$ & $\begin{array}{l}\Delta(\mathbf{1 1}) \\
(13)\end{array}$ & $\begin{array}{l}\Delta(\mathbf{1 2}) \\
(14)\end{array}$ & $\begin{array}{l}(\mathbf{1 4})-(\mathbf{1 3}) \\
(15)\end{array}$ \\
\hline \multirow[t]{3}{*}{ Namibia } & 2000 & 78.5 & 83.1 & - & - & - & 87.5 & 90.6 & - & - & - & 75.7 & 80.5 & - & - & - \\
\hline & 2006 & $\begin{array}{l}{[77.1,79.8]} \\
83.8\end{array}$ & $\begin{array}{l}{[81.5,84.5]} \\
84.8\end{array}$ & 09 & 03 & -06 & {$[86.5,88.6]$} & {$[89.5,91.7]$} & 06 & 0 & -04 & $\begin{array}{l}{[73.5,77.9]} \\
778\end{array}$ & {$[78.0,83.0]$} & & & 07 \\
\hline & & {$[82.9,84.7]$} & {$[83.6,86.0]$} & {$[0.6,1.2]$} & {$[-0.1,0.6]$} & {$[-1.1,-0.2]$} & {$[90.4,91.7]$} & {$[90.8,92.6]$} & {$[0.4,0.8]$} & {$[-0.1,0.4]$} & {$[-0.7,-0.1]$} & {$[76.0,79.6]$} & {$[76.0,80.6]$} & {$[-0.1,0.8]$} & {$[-0.9,0.2]$} & {$[-1.4,0.0]$} \\
\hline \multirow[t]{6}{*}{ Nepal } & 2001 & 26.9 & 34.4 & - & - & - & 33.3 & 41.5 & - & - & - & 60.4 & 68.8 & - & - & - \\
\hline & & {$[25.9,28.1]$} & {$[32.9,35.8]$} & & & & {$[32.3,34.4]$} & {$[40.1,43.0]$} & & & & {$[58.1,62.6]$} & {$[65.6,71.9]$} & & & \\
\hline & 2006 & 37.5 & 37.3 & 2.1 & 0.6 & -1.5 & 47.3 & 48.4 & 2.8 & 1.4 & -1.4 & 66.5 & 70.4 & 1.2 & 0.3 & -0.9 \\
\hline & & {$[36.2,38.8]$} & {$[35.5,39.1]$} & {$[1.8,2.5]$} & {$[0.1,1.0]$} & {$[-2.1,-0.9]$} & {$[46.0,48.5]$} & {$[46.4,50.2]$} & {$[2.5,3.1]$} & {$[0.9,1.8]$} & {$[-2.0,-0.9]$} & {$[64.6,68.4]$} & {$[67.2,73.6]$} & {$[0.6,1.8]$} & {$[-0.6,1.2]$} & {$[-2.0,0.2]$} \\
\hline & 2011 & 52.0 & 43.5 & 2.9 & 1.2 & -1.7 & 61.4 & 54.2 & 2.8 & 1.2 & -1.7 & 78.5 & 74.3 & 2.4 & 0.8 & -1.6 \\
\hline & & {$[50.8,53.3]$} & {$[41.7,45.2]$} & {$[2.5,3.3]$} & {$[0.7,1.7]$} & {$[-2.3,-1.0]$} & {$[60.2,62.5]$} & {$[52.3,55.9]$} & {$[2.5,3.2]$} & {$[0.6,1.7]$} & {$[-2.3,-1.0]$} & {$[76.6,80.3]$} & {$[71.5,77.0]$} & {$[1.9,2.9]$} & {$[-0.1,1.6]$} & {$[-2.6,-0.6]$} \\
\hline \multirow[t]{4}{*}{ Nigeria } & 2003 & 39.3 & 46.5 & - & - & - & 44.8 & 51.6 & - & - & - & 64.7 & 74.0 & - & - & - \\
\hline & & {$[37.6,41.0]$} & {$[44.5,48.4]$} & & & & {$[43.2,46.5]$} & {$[49.4,53.7]$} & & & & {$[61.9,67.4]$} & {$[70.7,77.2]$} & & & \\
\hline & 2008 & 44.0 & 44.5 & 0.9 & -0.4 & -1.3 & 50.9 & 51.9 & 1.2 & 0.1 & -1.2 & 63.2 & 65.7 & -0.3 & -1.7 & -1.4 \\
\hline & & {$[43.4,44.7]$} & {$[43.7,45.3]$} & {$[0.6,1.3]$} & {$[-0.8,0.0]$} & {$[-1.9,-0.8]$} & {$[50.3,51.5]$} & {$[50.9,52.7]$} & {$[0.9,1.6]$} & {$[-0.4,0.5]$} & {$[-1.8,-0.6]$} & {$[62.3,64.0]$} & {$[64.5,66.9]$} & {$[-0.9,0.3]$} & {$[-2.4,-1.0]$} & {$[-2.3,-0.4]$} \\
\hline \multirow[t]{4}{*}{ Pakistan } & 2006 & 29.0 & 34.8 & - & - & - & 35.8 & 41.9 & - & - & - & & & & & \\
\hline & & {$[27.9,30.2]$} & {$[33.4,36.4]$} & & & & {$[34.6,37.1]$} & {$[40.4,43.4]$} & & & & & & & & \\
\hline & 2012 & 39.1 & 40.7 & 1.7 & 1.0 & -0.7 & 43.5 & 44.8 & 1.3 & 0.5 & -0.8 & & & & & \\
\hline & & {$[38.0,40.2]$} & {$[39.1,42.2]$} & {$[1.4,1.9]$} & {$[0.6,1.3]$} & {$[-1.2,-0.3]$} & {$[42.3,44.6]$} & {$[43.4,46.5]$} & {$[1.0,1.6]$} & {$[0.1,0.8]$} & {$[-1.2,-0.3]$} & & & & & \\
\hline \multirow[t]{6}{*}{ Peru } & 2000 & 84.8 & 88.9 & - & - & - & 90.0 & 93.2 & - & - & - & & & & & \\
\hline & & {$[84.3,85.3]$} & {$[88.3,89.5]$} & & & & {$[89.5,90.4]$} & {$[92.8,93.6]$} & & & & & & & & \\
\hline & 2007 & 87.6 & 87.3 & 0.4 & -0.2 & -0.6 & 92.0 & 92.0 & 0.3 & -0.2 & -0.5 & & & & & \\
\hline & & {$[87.2,88.0]$} & {$[86.7,87.9]$} & {$[0.3,0.5]$} & {$[-0.3,-0.1]$} & {$[-0.8,-0.5]$} & {$[91.7,92.4]$} & {$[91.6,92.5]$} & {$[0.2,0.4]$} & {$[-0.3,-0.1]$} & {$[-0.6,-0.3]$} & & & & & \\
\hline & 2012 & 90.2 & 87.3 & 0.5 & 0.0 & -0.5 & 93.7 & 91.8 & 0.3 & 0.0 & -0.4 & & & & & \\
\hline & & {$[89.7,90.7]$} & {$[86.5,88.1]$} & {$[0.4,0.6]$} & {$[-0.2,0.2]$} & {$[-0.7,-0.3]$} & {$[93.3,94.1]$} & {$[91.2,92.4]$} & {$[0.2,0.4]$} & {$[-0.2,0.1]$} & {$[-0.6,-0.2]$} & & & & & \\
\hline \multirow[t]{4}{*}{ Philippines } & 2003 & 92.2 & 94.1 & - & - & - & 96.5 & 97.2 & - & - & - & & & & & \\
\hline & & {$[91.7,92.7]$} & {$[93.5,94.6]$} & & & & {$[96.2,96.9]$} & {$[96.8,97.6]$} & & & & & & & & \\
\hline & 2008 & 92.4 & 93.0 & 0.0 & -0.2 & -0.2 & 97.0 & 97.4 & 0.1 & 0.0 & -0.1 & & & & & \\
\hline & & {$[91.8,92.9]$} & {$[92.4,93.7]$} & {$[-0.1,0.2]$} & {$[-0.4,0.0]$} & {$[-0.5,0.0]$} & {$[96.7,97.3]$} & {$[97.0,97.8]$} & {$[0.0,0.2]$} & {$[-0.1,0.1]$} & {$[-0.2,0.1]$} & & & & & \\
\hline
\end{tabular}


Table 1: continued

\begin{tabular}{|c|c|c|c|c|c|c|c|c|c|c|c|c|c|c|c|c|}
\hline \multirow[b]{3}{*}{ country } & \multirow[b]{3}{*}{ year } & \multicolumn{10}{|c|}{ female } & \multirow{2}{*}{\multicolumn{5}{|c|}{$\begin{array}{c}\text { male } \\
\text { full literacy }\end{array}$}} \\
\hline & & \multicolumn{5}{|c|}{ full literacy } & \multicolumn{5}{|c|}{ partial literacy } & & & & & \\
\hline & & $\begin{array}{l}\text { period } \\
\text { (1) }\end{array}$ & $\begin{array}{l}\text { cohort } \\
(2)\end{array}$ & $\begin{array}{l}\Delta(1) \\
(3)\end{array}$ & $\begin{array}{l}\Delta(2) \\
(4)\end{array}$ & $\begin{array}{l}(4)-(3) \\
(5)\end{array}$ & $\begin{array}{l}\text { period } \\
\text { (6) }\end{array}$ & $\begin{array}{l}\text { cohort } \\
(7)\end{array}$ & $\begin{array}{l}\Delta(6) \\
(8)\end{array}$ & $\begin{array}{l}\Delta(7) \\
(9)\end{array}$ & $\begin{array}{l}(\mathbf{9})-(\mathbf{8}) \\
(10)\end{array}$ & $\begin{array}{l}\text { period } \\
(11)\end{array}$ & $\begin{array}{l}\text { cohort } \\
(12)\end{array}$ & $\begin{array}{l}\Delta(11) \\
(13)\end{array}$ & $\begin{array}{l}\Delta(12) \\
(14)\end{array}$ & $\begin{array}{l}(14)-(13) \\
(15)\end{array}$ \\
\hline \multirow[t]{3}{*}{ Rwanda } & 2000 & $\begin{array}{l}55.3 \\
{[54.1,56.4]}\end{array}$ & $\begin{array}{l}66.8 \\
{[65.3,68.1]}\end{array}$ & - & - & - & $\begin{array}{l}63.0 \\
{[61.9,64.2]}\end{array}$ & $\begin{array}{l}73.6 \\
{[72.2,74.9]}\end{array}$ & - & - & - & $\begin{array}{l}67.3 \\
{[65.1,69.7]}\end{array}$ & $\begin{array}{l}73.4 \\
{[70.3,76.4]}\end{array}$ & - & - & - \\
\hline & 2005 & $\begin{array}{l}57.0 \\
{[55.8,58.0]}\end{array}$ & $\begin{array}{l}62.4 \\
{[60.9,63.8]}\end{array}$ & $\begin{array}{l}0.3 \\
{[0.0,0.6]}\end{array}$ & $\begin{array}{l}-0.9 \\
{[-1.3,-0.5]}\end{array}$ & $\begin{array}{l}-1.2 \\
{[-1.7,-0.7]}\end{array}$ & $\begin{array}{l}67.8 \\
{[66.8,68.8]}\end{array}$ & $\begin{array}{l}72.7 \\
{[71.4,74.2]}\end{array}$ & $\begin{array}{l}1.0 \\
{[0.6,1.3]}\end{array}$ & $\begin{array}{l}-0.2 \\
{[-0.6,0.2]}\end{array}$ & $\begin{array}{l}-1.1 \\
{[-1.6,-0.6]}\end{array}$ & $\begin{array}{l}67.0 \\
{[65.4,68.6]}\end{array}$ & $\begin{array}{l}71.3 \\
{[68.9,73.6]}\end{array}$ & $\begin{array}{l}-0.1 \\
{[-0.7,0.5]}\end{array}$ & $\begin{array}{l}-0.4 \\
{[-1.2,0.3]}\end{array}$ & $\begin{array}{l}-0.4 \\
{[-1.3,0.6]}\end{array}$ \\
\hline & 2010 & $\begin{array}{l}64.7 \\
{[63.8,65.7]}\end{array}$ & $\begin{array}{l}64.5 \\
{[62.9,66.0]}\end{array}$ & $\begin{array}{l}1.6 \\
{[1.3,1.9]}\end{array}$ & $\begin{array}{l}0.4 \\
{[0.0,0.9]}\end{array}$ & $\begin{array}{l}-1.1 \\
{[-1.7,-0.6]}\end{array}$ & $\begin{array}{l}73.8 \\
{[72.9,74.7]}\end{array}$ & $\begin{array}{l}73.3 \\
{[72.0,74.6]}\end{array}$ & $\begin{array}{l}1.2 \\
{[0.9,1.5]}\end{array}$ & $\begin{array}{l}0.1 \\
{[-0.3,0.5]}\end{array}$ & $\begin{array}{l}-1.1 \\
{[-1.5,-0.6]}\end{array}$ & $\begin{array}{l}71.0 \\
{[69.7,72.3]}\end{array}$ & $\begin{array}{l}74.3 \\
{[72.2,76.5]}\end{array}$ & $\begin{array}{l}0.8 \\
{[0.4,1.2]}\end{array}$ & $\begin{array}{l}0.6 \\
{[0.0,1.2]}\end{array}$ & $\begin{array}{l}-0.2 \\
{[-0.9,0.6]}\end{array}$ \\
\hline \multirow[t]{2}{*}{ Senegal } & 2005 & $\begin{array}{l}24.5 \\
{[23.4,25.7]}\end{array}$ & $\begin{array}{l}26.9 \\
{[25.5,28.2]}\end{array}$ & - & - & - & $\begin{array}{l}32.1 \\
{[31.0,33.3]}\end{array}$ & $\begin{array}{l}35.5 \\
{[33.9,36.9]}\end{array}$ & - & - & - & $\begin{array}{l}42.8 \\
{[40.2,45.4]}\end{array}$ & $\begin{array}{l}47.1 \\
{[44.0,50.4]}\end{array}$ & - & - & - \\
\hline & 2010 & $\begin{array}{l}23.9 \\
{[22.8,25.1]}\end{array}$ & $\begin{array}{l}22.2 \\
{[20.7,23.8]}\end{array}$ & $\begin{array}{l}-0.1 \\
{[-0.5,0.2]}\end{array}$ & $\begin{array}{l}-0.9 \\
{[-1.4,-0.5]}\end{array}$ & $\begin{array}{l}-0.8 \\
{[-1.3,-0.3]}\end{array}$ & $\begin{array}{l}33.2 \\
{[31.9,34.3]}\end{array}$ & $\begin{array}{l}31.5 \\
{[29.9,33.1]}\end{array}$ & $\begin{array}{l}0.2 \\
{[-0.1,0.6]}\end{array}$ & $\begin{array}{l}-0.8 \\
{[-1.2,-0.4]}\end{array}$ & $\begin{array}{l}-1.0 \\
{[-1.6,-0.5]}\end{array}$ & $\begin{array}{l}40.6 \\
{[38.4,42.8]}\end{array}$ & $\begin{array}{l}39.6 \\
{[36.3,42.8]}\end{array}$ & $\begin{array}{l}-0.5 \\
{[-1.1,0.2]}\end{array}$ & $\begin{array}{l}-1.5 \\
{[-2.4,-0.6]}\end{array}$ & $\begin{array}{l}-1.0 \\
{[-2.1,0.0]}\end{array}$ \\
\hline \multirow[t]{3}{*}{ Uganda } & 2000 & $\begin{array}{l}46.0 \\
{[44.5,47.5]}\end{array}$ & $\begin{array}{l}48.2 \\
{[46.3,49.9]}\end{array}$ & - & - & - & $\begin{array}{l}55.8 \\
{[54.3,57.3]}\end{array}$ & $\begin{array}{l}58.9 \\
{[57.1,60.7]}\end{array}$ & - & - & - & $\begin{array}{l}67.0 \\
{[64.0,69.8]}\end{array}$ & $\begin{array}{l}67.5 \\
{[63.9,71.0]}\end{array}$ & - & - & - \\
\hline & 2006 & $\begin{array}{l}44.9 \\
{[43.5,46.3]}\end{array}$ & $\begin{array}{l}43.7 \\
{[41.7,45.6]}\end{array}$ & $\begin{array}{l}-0.2 \\
{[-0.5,0.1]}\end{array}$ & $\begin{array}{l}-0.7 \\
{[-1.2,-0.3]}\end{array}$ & $\begin{array}{l}-0.6 \\
{[-1.1,0.0]}\end{array}$ & $\begin{array}{l}54.1 \\
{[52.8,55.5]}\end{array}$ & $\begin{array}{l}53.1 \\
{[51.3,55.0]}\end{array}$ & $\begin{array}{l}-0.3 \\
{[-0.6,0.1]}\end{array}$ & $\begin{array}{l}-1.0 \\
{[-1.4,-0.5]}\end{array}$ & $\begin{array}{l}-0.7 \\
{[-1.2,-0.1]}\end{array}$ & $\begin{array}{l}68.3 \\
{[65.8,70.6]}\end{array}$ & $\begin{array}{l}68.4 \\
{[65.1,71.4]}\end{array}$ & $\begin{array}{l}0.2 \\
{[-0.4,0.8]}\end{array}$ & $\begin{array}{l}0.1 \\
{[-0.7,1.0]}\end{array}$ & $\begin{array}{l}-0.1 \\
{[-1.1,0.9]}\end{array}$ \\
\hline & 2011 & $\begin{array}{l}48.3 \\
{[46.9,49.7]}\end{array}$ & $\begin{array}{l}41.3 \\
{[39.1,43.5]}\end{array}$ & $\begin{array}{l}0.7 \\
{[0.3,1.1]}\end{array}$ & $\begin{array}{l}-0.5 \\
{[-1.1,0.1]}\end{array}$ & $\begin{array}{l}-1.2 \\
{[-1.9,-0.4]}\end{array}$ & $\begin{array}{l}61.1 \\
{[59.6,62.5]}\end{array}$ & $\begin{array}{l}55.4 \\
{[53.4,57.5]}\end{array}$ & $\begin{array}{l}1.4 \\
{[1.0,1.8]}\end{array}$ & $\begin{array}{l}0.5 \\
{[-0.1,1.0]}\end{array}$ & $\begin{array}{l}-0.9 \\
{[-1.6,-0.3]}\end{array}$ & $\begin{array}{l}62.4 \\
{[59.7,65.0]}\end{array}$ & $\begin{array}{l}64.3 \\
{[60.4,68.1]}\end{array}$ & $\begin{array}{l}-1.2 \\
{[-1.9,-0.4]}\end{array}$ & $\begin{array}{l}-0.8 \\
{[-1.8,0.2]}\end{array}$ & $\begin{array}{l}0.4 \\
{[-0.8,1.6]}\end{array}$ \\
\hline \multirow[t]{2}{*}{ URTanzania } & 2004 & $\begin{array}{l}61.2 \\
{[59.9,62.5]}\end{array}$ & $\begin{array}{l}65.0 \\
{[63.6,66.5]}\end{array}$ & - & - & - & $\begin{array}{l}66.4 \\
{[65.2,67.7]}\end{array}$ & $\begin{array}{l}70.0 \\
{[68.4,71.3]}\end{array}$ & - & - & - & $\begin{array}{l}75.4 \\
{[73.2,77.5]}\end{array}$ & $\begin{array}{l}72.8 \\
{[70.0,75.8]}\end{array}$ & - & - & - \\
\hline & 2010 & $\begin{array}{l}62.3 \\
{[61.0,63.6]}\end{array}$ & $\begin{array}{l}63.0 \\
{[61.1,64.9]}\end{array}$ & $\begin{array}{l}0.2 \\
{[-0.1,0.5]}\end{array}$ & $\begin{array}{l}-0.3 \\
{[-0.7,0.0]}\end{array}$ & $\begin{array}{l}-0.5 \\
{[-1.1,0.0]}\end{array}$ & $\begin{array}{l}68.2 \\
{[66.9,69.4]}\end{array}$ & $\begin{array}{l}68.1 \\
{[66.4,69.8]}\end{array}$ & $\begin{array}{l}0.3 \\
{[0.0,0.6]}\end{array}$ & $\begin{array}{l}-0.3 \\
{[-0.7,0.1]}\end{array}$ & $\begin{array}{l}-0.6 \\
{[-1.1,-0.1]}\end{array}$ & $\begin{array}{l}74.8 \\
{[72.3,77.3]}\end{array}$ & $\begin{array}{l}73.5 \\
{[70.1,76.8]}\end{array}$ & $\begin{array}{l}-0.1 \\
{[-0.7,0.5]}\end{array}$ & $\begin{array}{l}0.1 \\
{[-0.6,0.8]}\end{array}$ & $\begin{array}{l}0.2 \\
{[-0.7,1.2]}\end{array}$ \\
\hline \multirow[t]{2}{*}{ Zambia } & 2001 & $\begin{array}{l}52.6 \\
{[51.3,53.9]}\end{array}$ & $\begin{array}{l}53.2 \\
{[51.6,54.9]}\end{array}$ & - & - & - & $\begin{array}{l}62.0 \\
{[60.7,63.3]}\end{array}$ & $\begin{array}{l}62.5 \\
{[60.9,64.0]}\end{array}$ & - & - & - & $\begin{array}{l}73.5 \\
{[71.2,75.6]}\end{array}$ & $\begin{array}{l}70.7 \\
{[67.6,73.5]}\end{array}$ & - & - & - \\
\hline & 2007 & $\begin{array}{l}51.7 \\
{[50.2,53.1]}\end{array}$ & $\begin{array}{l}51.8 \\
{[49.8,53.8]}\end{array}$ & $\begin{array}{l}-0.2 \\
{[-0.5,0.2]}\end{array}$ & $\begin{array}{l}-0.2 \\
{[-0.7,0.2]}\end{array}$ & $\begin{array}{l}-0.1 \\
{[-0.6,0.5]}\end{array}$ & $\begin{array}{l}62.2 \\
{[60.9,63.7]}\end{array}$ & $\begin{array}{l}62.2 \\
{[60.2,64.1]}\end{array}$ & $\begin{array}{l}0.0 \\
{[-0.3,0.4]}\end{array}$ & $\begin{array}{l}0.0 \\
{[-0.4,0.4]}\end{array}$ & $\begin{array}{l}-0.1 \\
{[-0.6,0.4]}\end{array}$ & $\begin{array}{l}71.6 \\
{[70.3,73.0]}\end{array}$ & $\begin{array}{l}69.4 \\
{[67.6,71.4]}\end{array}$ & $\begin{array}{l}-0.3 \\
{[-0.8,0.1]}\end{array}$ & $\begin{array}{l}-0.2 \\
{[-0.8,0.4]}\end{array}$ & $\begin{array}{l}0.1 \\
{[-0.7,0.8]}\end{array}$ \\
\hline \multirow[t]{2}{*}{ Zimbabwe } & 2005 & $\begin{array}{l}78.8 \\
{[77.7,80.0]}\end{array}$ & $\begin{array}{l}85.6 \\
{[84.4,86.9]}\end{array}$ & - & - & - & $\begin{array}{l}90.4 \\
{[89.4,91.2]}\end{array}$ & $\begin{array}{l}95.7 \\
{[94.9,96.3]}\end{array}$ & - & - & - & $\begin{array}{l}87.6 \\
{[86.6,88.6]}\end{array}$ & $\begin{array}{l}91.0 \\
{[90.0,92.1]}\end{array}$ & - & - & - \\
\hline & 2010 & $\begin{array}{l}86.5 \\
{[85.6,87.3]}\end{array}$ & $\begin{array}{l}88.3 \\
{[87.2,89.4]}\end{array}$ & $\begin{array}{l}1.5 \\
{[1.2,1.8]}\end{array}$ & $\begin{array}{l}0.5 \\
{[0.2,0.9]}\end{array}$ & $\begin{array}{l}-1.0 \\
{[-1.4,-0.6]}\end{array}$ & $\begin{array}{l}93.3 \\
{[92.7,93.9]}\end{array}$ & $\begin{array}{l}94.6 \\
{[93.9,95.4]}\end{array}$ & $\begin{array}{l}0.6 \\
{[0.4,0.8]}\end{array}$ & $\begin{array}{l}-0.2 \\
{[-0.4,0.0]}\end{array}$ & $\begin{array}{l}-0.8 \\
{[-1.1,-0.5]}\end{array}$ & $\begin{array}{l}89.5 \\
{[88.6,90.3]}\end{array}$ & $\begin{array}{l}90.9 \\
{[89.8,91.9]}\end{array}$ & $\begin{array}{l}0.4 \\
{[0.1,0.6]}\end{array}$ & $\begin{array}{l}0.0 \\
{[-0.3,0.3]}\end{array}$ & $\begin{array}{l}-0.4 \\
{[-0.8,0.0]}\end{array}$ \\
\hline
\end{tabular}




\section{References}

Abadzi, H. 2004. Strategies and Policies for Literacy. Background Paper. Education for All Global Monitoring Report.

Acharya, S., and Bidya N. K. 2006. A Comprehensive Review of the Practices of Literacy and Nonformal Education in Nepal. Kathmandu Series of Monographs and Working Papers 11. UNESCO.

Ahmed, M. 2011. Defining and measuring literacy: Facing the reality. International Review of Education 57 (1/2): 179-195.

Aitchison, J., and Rule, P.. 2005. A Quick Survey of SADC Literacy Statistics and Projections. Background Paper. Education for All Global Monitoring Report.

Banister, J., and Zhang, X. 2004. China, Economic Development and Mortality Decline. World Development 33 (1): 21-41.

Barakat, B., Durham, R.E., and Rodrigues Guimarães, C. 2013. Age Compositional Adjustments for Educational Participation Indicators. Population 68 (4): 607-26.

Bhargava, A. 2008. Globalization, Literacy Levels, and Economic Development. Research Paper No. 2008/04. United Nations University World Institute for Development Economics Research (UNU-WIDER).

Bhola, H. S. 1984. A Policy Analysis of Adult Literacy Promotion in the Third World: An Accounting of Promises Made and Promises Fulfilled. International Review of Education 30(3), pp. 249-264.

Blinder, A. S. 1973. Wage discimination: Reduced form and structural estimates. Journal of Human Resources 8: 436-455.

Blunch, N.-H. 2012. Staying Alive: Adult Literacy Programs and Child Mortality in Rural Ghana. World Development 42: 114-126.

Blunch, N.-H., and Pörtner, C. 2011. Literacy, skills and welfare: Effects of participation in adult literacy programs. Economic Development and Cultural Change 60(1): 17-66.

Bostock, S., and Steptoe, A.. 2012. Association Between Low Functional Health Literacy and Mortality in Older Adults: Longitudinal Cohort Study. BMJ 344.

Carr-Hill, R. 2008. International Literacy Statistics: A Review of Concepts, Methodology and Current Data. UNESCO Institute for Statistics. 
Carr-Hill, R., Roberts, F., and Currie, E. 2010. Approaches to costing adult literacy programmes, especially in Africa. International Journal of Educational Development 30: 428 -437.

Cárceles, G. 1990. World Literacy Prospects at the Turn of the Century: Is the Objective of Literacy for All by the Year 2000 Statistically Plausible? Comparative Education Review 34 (1): $4-20$.

Clemens, M. A., Kenny, C. J., and Moss, T. J. 2007. The Trouble with the MDGs: Confronting Expectations of Aid and Development Success. World Development 35 (5): 735-751.

Chudgar, A. 2009. The Challenge of Universal Elementary Education in Rural India: Can Adult Literacy Play a Role?. Comparative Education Review 53 (3): 403-433.

Dakar Framework for Action, Education for All: Meeting Our Collective Commitments. 2000. UNESCO.

Darcovich, N. 2000. The Measurement of Adult Literacy in Theory and in Practice. International Review of Education 46 (5): 367-376.

Durgunoglu, A. Y., Öney, B., and Kusçul, H. 2003. Development and evaluation of an adult literacy program in Turkey. International Journal of Educational Development 23: 17-36.

Dyer, C. 2000. 'Education for All' and the Rabaris of Kachchh, Western India. International Journal of Educational Research 33: 241-251.

Easterly, W. 2009. How the Millennium Development Goals are Unfair to Africa. World Development 37 (1): 26-35.

Fortin, N., Lemieux, T., and Firpo, S.. 2011. Decomposition Methods in Economics (with Sergio Firpo and Nicole Fortin), in D. Card and O. Ashenfelter, eds., Handbook of Labor Economics, 4 th Edition, Elsevier North Holland, pp. 1-102.

Fortson, J. G. 2008. The Gradient in Sub-Saharan Africa: Socioeconomic Status and HIV/AIDS. Demography 45 (2): 303-22.

Grosse, R. N., and Auffrey, C. 1989. Literacy and Health Status in Developing Countries. Annual Review of Public Health 10 (1): 281-97.

Guodong, X., and Z. Zhupeng. 2003. Meeting the Basic Learning Needs of the Newly Literate: China's Post-Literacy Education for the Early 21st Century. International Review of Education 49 (6): 621-629.

Hamilton, M., and D. Barton. 2000. The International Adult Literacy Survey: What Does It Really Measure?. International Review of Education 46 (5): 377-389. 
Hamilton, M., and Pitt, K. 2011. Changing policy discourses: Constructing literacy inequalities. International Journal of Educational Development 31: 596-605.

Hanemann, U. 2012. Looking Forward with LIFE: Literacy Initiative for Empowerment. Global LIFE Mid-term Evaluation Report 2006-2011. Hamburg, Germany: UNESCO Institute for Lifelong Learning (UIL).

Hargreaves, J. R., Bonell, C. P., Boler, T., Boccia, D., Birdthistle, I., Fletcher, A., Pronyk, P. M., and Glynn, J. R. 2008. Systematic Review Exploring Time Trends in the Association Between Educational Attainment and Risk of HIV Infection in Sub-Saharan Africa. AIDS 22 (3): 403-14. Iorio, D., and Santaeulàlia-Llopis, R.. 2011. Education, HIV Status, and Risky Sexual Behavior: How Much Does the Stage of the HIV Epidemic Matter? Working Papers 624. Barcelona Graduate School of Economics.

Limage, L. 2005. The Growth of Literacy in Historic Perspective: Clarifying the Role of Formal Schooling and Adult Learning Opportunities. Background Paper 2006/ED/EFA/MRT/PI/54. Education for All Global Monitoring Report.

Lutz, W., and Goujon, A. 2005. Literacy Projections. Background Paper. Education for All Global Monitoring Report.

Maruatona, T. 2008. Reflections on Policies for Mass Literacy Education in sub-Saharan Africa. International Review of Education 54 (5/6): 745-754.

Mpofu, S. T., and F. Youngman. 2001. The Dominant Tradition in Adult Literacy: A Comparative Study of National Literacy Programmes in Botswana and Zimbabwe. International Review of Education 47 (6): 573-595.

Nath, S. R. 2007. Self-Reporting and Test Discrepancy: Evidence from a National Literacy Survey in Bangladesh. International Review of Education 53 (2): 119-133.

Oaxaca, R. 1973. Male-female wage differentials in urban labor markets. International Economic Review 14: 693-709.

Ortega, D., and Rodriguez, F. 2008. Freed from illiteracy? A closer look at Venezuela's Mision Robinson literacy campaign. Economic Development and Cultural Change 57 (1): 1-30.

Reder, S., and Bynner, J. 2008. Tracking Adult Literacy and Numeracy Skills: Findings from Longitudinal Research. Routledge.

Robinson, C. 2005. Promoting literacy: What is the record of Education for All? International Journal of Educational Development 25: 436-444. 
Schell, C. O., Reilly, M., Rosling, H., Peterson, S., and Ekström, A. M. 2007. Socioeconomic determinants of infant mortality: A worldwide study of 152 low-, middle-, and high-income countries. Scandinavian Journal of Public Health: 35 (3): 288-297.

Sharrow, D. J. 2013. HIV.LifeTables: HIV Calibrated Model Life Tables for Countries with Generalized HIV Epidemics. http://CRAN.R-project.org/package=HIV.LifeTables.

Siegel, J.S., Swanson, D., and Shryock, H.S. 2004. The Methods and Materials of Demography. Emerald.

Spaull, N., and Taylor, S. 2015. Access to What? Creating a Composite Measure of Educational Quantity and Educational Quality for 11 African Countries. Comparative Education Review 59 (1): pp. 133-65.

UNESCO. 1995. Compendium of Statistics on Illiteracy: 1995 Edition. UNESCO.

—. 2005. EFA Global Monitoring Report 2006: Literacy for Life. UNESCO.

Wagner, D. A. 2008. Adult Literacy: Monitoring and Evaluation for Practice and Policy. International Review of Education 54 (5/6): 651-672.

Wagner, D. A., and Castillo, N. M. 2014. Learning at the Bottom of the Pyramid: Constraints, Comparability and Policy in Developing Countries. Prospects 44 (4): 627-38. doi:10.1007/s11125014-9328-8. 


\section{Supplementary Material}

\section{Adult literacy programmes}

Given Nepal's apparently substantial decline in illiteracy of the adult female cohorts examined here, it is of particular interest is whether this can be attributed to successful literacy programming. As an additional comparison, Peru is chosen on account of having the largest reported programme participation among the countries investigated.

Figure 8 presents the results for the same female cohorts that were also analysed in the preceding sections, i.e., those aged 20-34 at the time of the first survey. It shows the shares in each of four categories cross-classified by whether they ever participated in a literacy programme and by literacy status, for women with non-missing entries for both variables. The existence of large-scale literacy programming is reflected in the fact that in Nepal about 1-in-8 more such women reported having participated in such a programme in 2011 compared to 2001, and around 1-in-5 in Peru over a similar period.

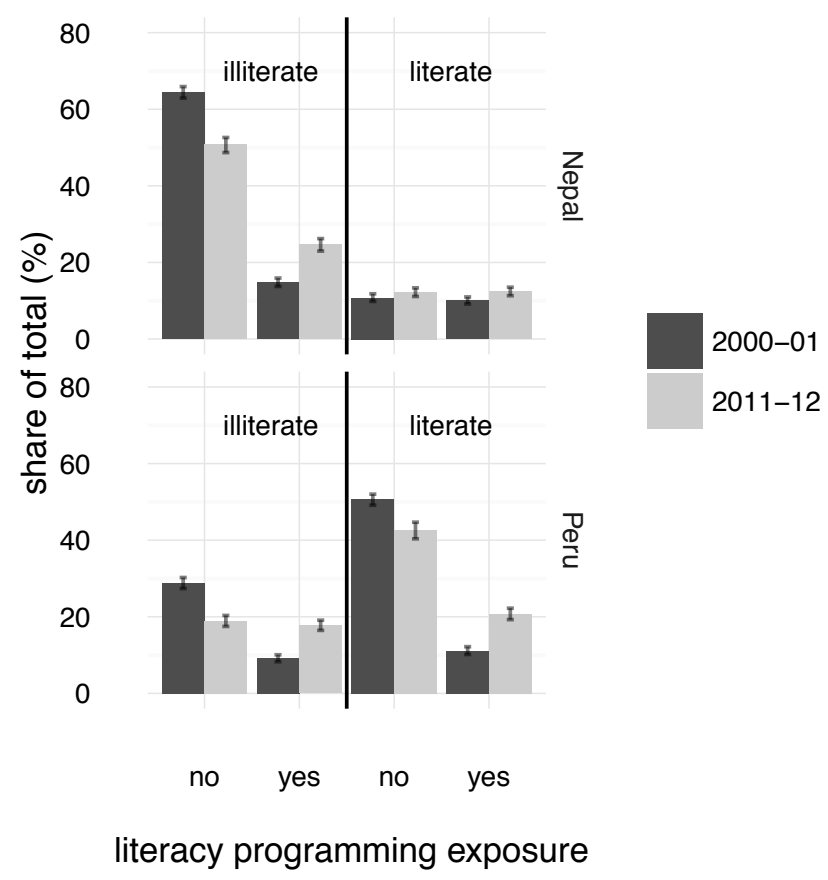

Figure 8: Females aged 20-34 at the first survey in each country, cross-classified by literacy status and reported exposure to adult literacy programmes. Bootstrapped $95 \%$ confidence intervals shown. Data: DHS.

For present purposes, the key observation is that the increase in the share of literate women with programme exposure in Nepal is only around 2 points. This is a mere fraction of the 9 point increase in the literacy rate of the full cohort reported in Table 1. It is also no larger than 
the increase in the share of literate women without programme exposure. In order words, the marginal literacy gain was shared by programme participants and non-participants alike.

The increase in the share of literate programme participants is also modest compared to the increasing share of illiterate programme participants. This comparison does not directly translate into an estimate of the 'success' rate of the literacy programmes, which cannot be determined without several additional assumptions regarding flows back from literacy to illiteracy, for instance. Two approximations were calculated. The first assumes that the literate programme graduates are drawn proportionately from the illiterate and literate participants. This is likely to wildly overestimate programme success. The second estimate assumes 'new' literate programme participants were already literate, to the extent allowed by the observed decline (if any) in literate non-participants. Between these two models, the resulting confidence intervals for the success rate range from essentially zero to only about 1-in-3 for programme participants becoming literate.

Restricting the analysis only to unschooled women results in even smaller apparent gains in literacy among programme participants. Unfortunately, it is not possible to disentangle in the absence of longitudinal data whether this means that, in terms of being able to benefit from adult literacy schemes, having been exposed to primary schooling as a child is an advantage, even if it did not lead to literacy at the time, or whether successful literacy programme participants continued on to get late formal attainment.

In sum, regardless of whether the literacy programmes in question can be considered to have been successful on their own terms, arithmetically they simply do not amount to an explanation for the increase in cohort literacy apparent in the Nepali sample. 


\section{Historic literacy outcomes under school expansion}

Having identified countries where literacy gains at adult ages have been marginal, we can exploit this knowledge to reconstruct an approximate time-series of the literacy outcomes of successive school-leaving cohorts. One use of such estimates is to compare them to the time-series of participation in schooling. In particular, it may shed some light on the old question of whether expansion comes at the expense of quality. In Figure 9, this is operationalised by plotting the literacy rate among primary school graduates against the share who completed at least primary school. Evidently, the historic experience in the countries examined provides no evidence to support the notion expanded participation was accompanied by deteriorating outcomes, at least not with respect to literacy. If anything, the opposite is true in the DHS sample: the more individuals have attended school, the higher the literacy rate among them. As a matter of fact, the results shown are highly conservative and understate the positive relationship by focusing on the literacy of those who completed at most primary school. Including all primary school graduates, including those that subsequentely progressed to higher levels, shows a dramatically more positive relationship still.

These results by themselves are not conclusive, and a full analysis of the interplay between the expansion in participation in formal schooling and its literacy outcomes would require additional analyses; They do, however, fit well with the entirely independent analysis conducted in the 2006 GMR (UNESCO 2005, 253) based on results of the Southern and Eastern African Consortium for Monitoring Educational Quality (SACMEQ II) assessment, that likewise show a positive correlation between aggregate participation and conditional literacy outcomes, as well as other recent research (Spaull and Taylor 2015) on this question. 


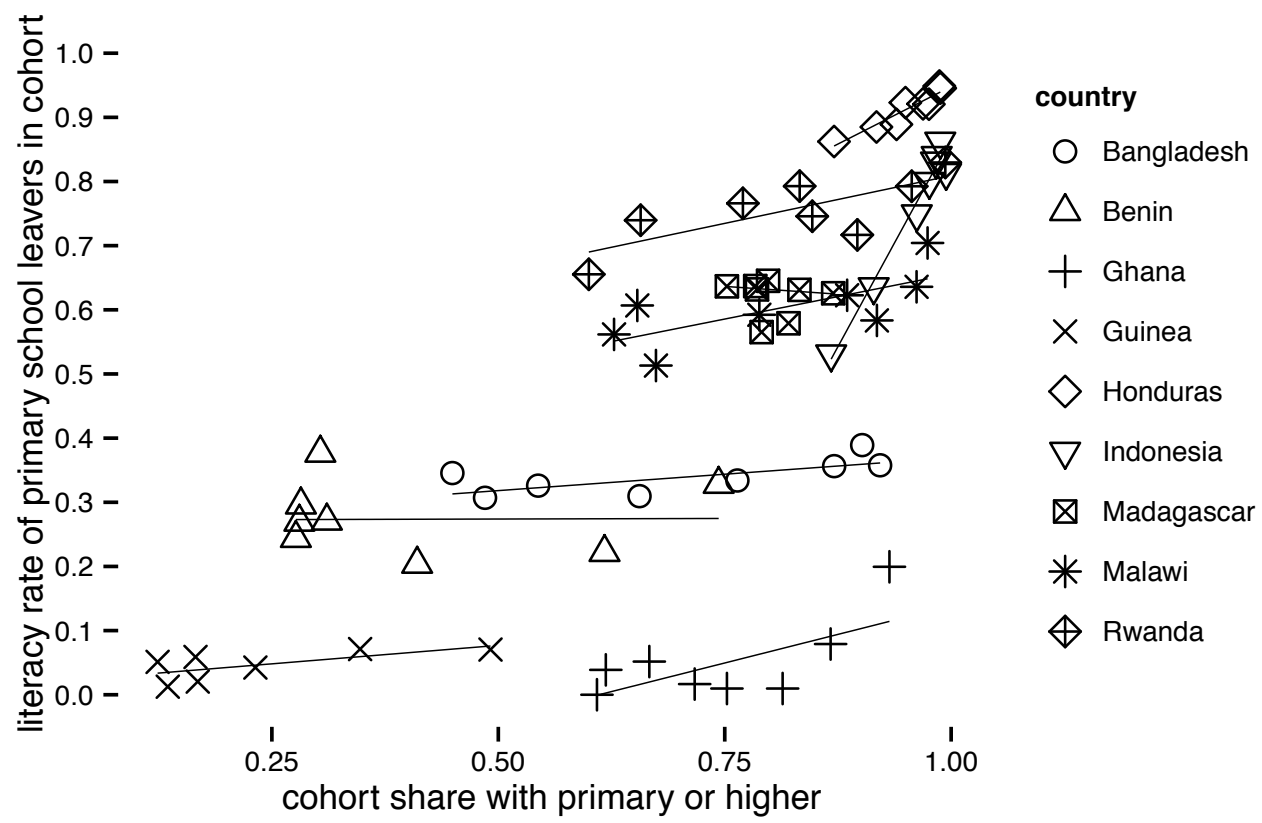

Figure 9: Literacy schooling outcomes among female primary only graduates by primary participation across cohorts, for countries with minimal cohort literacy drift and change of at least 0.1 in the share of primary graduates. Robust linear regression lines shown. Data: DHS 